\title{
Den sonderjydske Digterinde Anna (Anna Kristjane Lautrup).
}

Af Morten Eskesen

Tinglev Sogn ligrger omtrent midt i Sonderjylland, eller vi kan vel sige, milt $i$ en lige Linie mellem Skodborghus ved Kongeâen og Dannevirke ved Treâen (Treja) samt ligeledes midt i en lige Linie mellem Sønderborg og Hojer. Tinglev'Station ligger ved Jærnvejen mellem Vamdrup og Rendsborg, hvor Jærnvejen går fra til Tonder. Fỉ Minuters Gang i Vest ligger Tinglev Kirke med sit høje, slanke gennembrudte Spir, hrorfra der kan tælles 22 Kirker. I Tinglev By ligger nordvestlig nedenfor Kirkegården Tinglev Præsteg̊and, i hris Nabolag der indtil Efteråret 1892 la to gamle Huse, hror Digterinden Annas Forældre vare føalte.

I det ene af nærnte Huse boede ved Midten af forrige Hundredâr Møllebyggeren Bonnik Andresen med sin Hustru Kirstine Poulsen. Manden stammede fra Boldiksum 1å Før, hvorfra Stamfaderen var kommen til Medelly. Af Bonnik Andresens Born nævnes to Sonner og en Datter. Den ældste Søn Andreas boede i Tinglev og var Snedker; Skoleholder og Spillemand, havde glimrende Erner, men tog sig vel ofte en Tår over Tørsten. Hans Søn Bonnik Andreas Bonniksen blev Præst, f(xrst i Dybbol og siden i Hejls, hror imidlertid hrerken den kirkelige eller 
danskfolkelige Vækkelse faldt i hans Smag. Hans Søster Anna Kirstine Bonniksen var gift med Præst Peter Kjer i Østerlygum ( $†$ 12.Januar 1834). Hun havde tre Børn: Hans Andreas, Johan Kristjan og Anna Eugenia, hvilken sidste blev gift med Bonden $R$ asmus Callesen p i Lerskov, en Gard, som er bleven delt imellem to af hendes Børn, af hvilke Nis Callesen er kendt som en af de danske Sønderjyders Tillidsinæund og som en af Prof. Svend Grundtvigs Medarbejdere ved Optegnelsen af Egnens gamle Sagn, Sange og Aventyr og som en Mand, i hvis Hjem Børneundervisningen med stort Held har været dyrket som Husflid. „Hele Slægten har,“ skriver Nis Callesen, „lige indtil nu udmærket sig ved en medfødt Dygtighed til at arbejde i Træ (Træskærerkunst) og Kunstmaling. "

Men vi må vende tilbage til Møllebyggerens i Tinglev. Bonnik Andresens anden Søn Jes kom til Før og boede i Fællebyen Boldiksum. Af hans fire Dotre var den ældste Mantje (Narie) gift med en Lohnann i Tonder. Foruden hende nævnes Kåke, Engel og Enke (Inge, samme Navn, som hos Præstefolkene i Østerlygum blev til Eugenia og som Nis Callesen har "restaureret" til Jeng).

Møllebygger Bonnik Andresens Datter Anna Bonniksen var føalt den 15. Febr. 1749. Hun var altsi i sit femtende Ar, da Ulrik Anton Petersen fra Sønderborg 1763 blev Præst i Tinglev, så Anna må være blevet en af hans første Konfirmander, og jeg slutter mig til, at hun siden kom til at tjene i Præstegârden og var der i mange År som Husjomfru. Men samme År som Tinglev fik sin ny Præst, som blev der i toogfyrretyve $\hat{A} r$ som Sognepræst, fordtes den 20. Januar 1763 Joh an K ristjan Lorenzen Lauterup. Hans Forældre, Smmanden Lorenz 



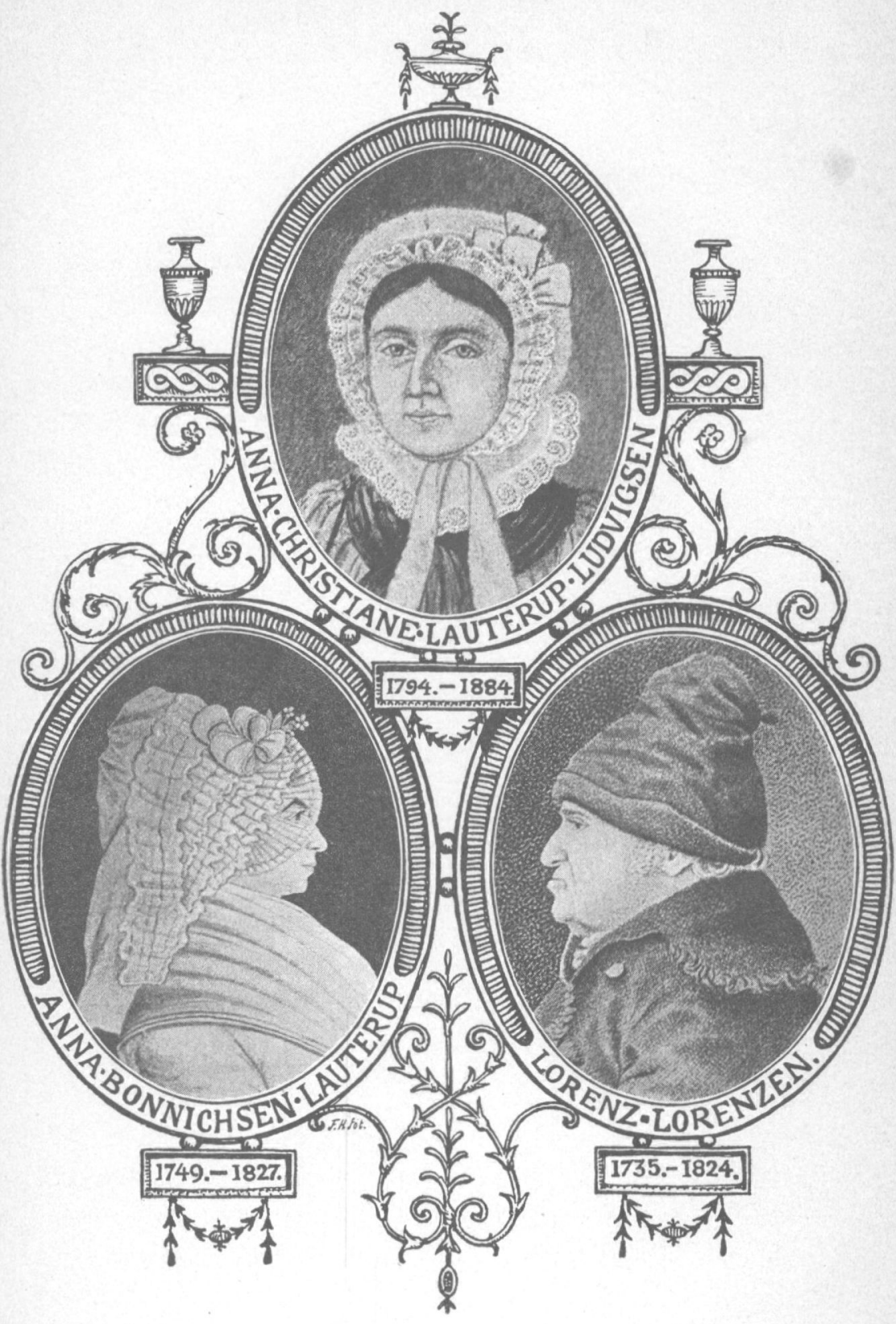


Lorenzen (fod 20. August 1334, dod 12. Januar 18:4) og Hustru Johanne Kristjane Lautrup boede i det anilet af de to Huse ved Prostegirilen. Navnet Lautrup stanmer selvfolgelig fra Landshyen Lautrup, som er lagt ind under Cuge Sogn, men i gamle Dage horte til Tinglev og gav hele Herredet, som nu hedder Slogs Herred Navn af Lavtrup Herred („Loctorn“). Efter Navnet at dฒmmme, må Johanne Kristjane have været i meget nær Slæugt med den Johan Kristjan Lautrup, der 4. Dechr. 1803 dode som Sognepræst i Tyrstrup og som var Fader til Præst Erasmus Lautrup i Haderslev (forl i Tyrstrup 15. Narts 1782, død i IIaderslev 12. Septbr. 1857) og Anna Salome Lautrup, dơ i Horslev Præstegård på Fyn 15. Juli 1833 efter 36 Års æoteskabeligt Samliv med Præst Rasmus Balslev, i hrilket hun blev Moder til fem Præster, af hvilke Biskop Balslev i Ribe efter Alder er den mellemste i Rækken og Præsten i Strø M. J. Balslev den yngste. Den ældste Johan Kristjan Balslev var i sin Tirl Præst på Sletten i Fyn. Af Sønnesønner er fein Præster pä Fyn ng tre i Jylland.

Sơmandens Sø̆n fra Tinglev skulde ogsá blive Præst. Sognepræsten U. A. Petersen tog sig af den raske lysøjede Dreng. Anna Bonnichsen og Farver Johansen i samme By hịalp med Penge. I sit tyvende År blev han da Student ved Kolhenhavns Universitet; men nxste Ăr tog han hjem og hlev Huslærer hos Farveren. 1787 gik has atter til Kobenhavn, hvor han 1789 tog Embedseksamen, og Iret efter blev han kaldet til Præst i Åbenrå. Han blev præsteviet den 26. April 1790. En Minerstid efter hlev Anna Bonnichsen hans Hustru og hun blev en sjaklen brav og dygtig Præstekone. Ft Billede af houde 
fra den Tid riser os hende som en skinn og kraftig Krinde med et lyst, klogt og tænksomt Ultryk. Nen hum var over $40 \hat{\mathrm{Ar}}$, da hun blev Hustru og orer 43 inden hun blev Moder. Ien 14. April 1794 fodtes Amma Kristjane Lautrup, som blev de lykkelige Egtefolks eneste Datter.

Kort efter hændte det en Dag, Moderen sad og syslede med sin lille Pige. Da bankedes der pai. Grsten, som trádte ind, rar en Mand med milde men skarpe ng blege Træk: Det var den narnkundige Sreitser Johan Kasper Lavater $(1741-1801)$, som var pâ Gennemrejse $0 \mathrm{~g}$, mens der skiftedes Heste, var smuttet hen for at lilse pa den unge l'ræst, der ligesom han selv havde havt meget ud af Tænkeren Ema nuel $\mathbf{K}$ a $\mathbf{t}$, ligesom Lavaters egne skrifter ogsia skattedes hojt her i Åbemri. Prostekonen lagile Barnet fra sig i Yugugen, men blev ikke glad, da hun horte, at den sjældne Gast umulig kunde tøve, til Præsten kom hjem fra Kirken, hvor han holdt Brudevielse. Lavater gik rask hen til Vuggen, lagde Hi̊nden pî Barnets Hoved, idet han sagde: "Gud velsigne Dig! Bliv Dine For:eldres Trøst og Glæde! Bliv god og ren i denne vildsonme Verden!" Han ilede bort. Men det hele gjorde et dybt Indtryk på Noderen og siden, ved hendes Omtale deraf, ourså på Datteren, især efter at Lavater var bleven fængslet pá Grund af sin Indsigelse mod det franske Folkeriges Overgreb imod Sveits og siden var død som Følge af en Snigmorders Skud 2. Januar 1807. Siden sang hun:

„For Brødres Held Du ofred Liv og Blod, Du Herrens Sanger! Martyr, Troens Kæmpe!

Ej Tid og Sted skal Glædens Luer dæmpe ved Tanken, at Du hos min Vugge stod! Et Lyspunkt er den mig i Vel og Ve', som blidt bestråle vil min Alders Sne. 
Du vied mig til Gud og Dyden ind; men ak, pâ Letsinds Sti jeg tidt har vandret, or glemt Dit Bud! - tilgiv at uforandret, en venlig Tanke huses $i$ mit Sind:

Den lille Sangens Guist, som bor i mig, o, Lavater! Ulev vakt til Liv af Dig!"

Den lille Kristjane var kun to År, da hendes Forældre fyttede fra Åbenrá til Brede, hvor Faderen derefter var Sognepræst i 49 Âr. Her i Brede Præstegâd voksede Kristjane da op under Indtryk af de store Tidender, de vældige Onskiftelser i Erropa og her hjemme, medens Napoleons Navn var jấ alles Læber. Dog var det ikke blot Krigstummelen, der optog den unge Piges Sind og Tanker, men en ung fransk Krigsmand tog hende med Storm, inden liun enduı var bleven moden Mo, og der var endogsî Tale om Strevnemoler. Hun synger ogsâ om en ung Franskmand: Jean Aug. Bicho, med ,Minespillets Ýnde, Øjets Ild og den varme Tale":

$$
\begin{aligned}
& \text { "Vove nogeu fræk Dig at fornærme, } \\
& \text { stol pá mig, jeg kommer snart igen, } \\
& \text { som en Dannerfjende eller Ven, } \\
& \text { lige meget! Dig jeg vil beskærme!“ }
\end{aligned}
$$

Hun ser ham grade og le som et Barn. Hun ser ham drømme sion som en Helt ind i Krigstummelen med den franske Ørn. Men hror blev han af? Blev han på Valpladsen? Hentæredes han på et Lazareth? Eller skulde han have glemt hende? I tlere af hendes Digte findes Spor af denne hendes forste Elskovsdrøm. Salledes i „Afskedsdagen“, „Den fjærne Grav" og „De gamle Minder". Et Brev gemmer hun som en Helligdom, en af Alderdom gulgrå Handske, som bares af den Hånd, der skrev Brevet, og en Rosenknop, som samme Hånd havde thettet den Elskede i Haret, og som sammen med Handsken og Brevet 
skal folge hente i Graven. Alt dette skal vel ikke sat lige tages bogstavelig, men har log sin Virkelighed til Baggrund.

Men Tiden var ilke blot en Napoleonstid. Den var ogsa en Tæukningrens Tid, der havde både sin Fichte og sin Henrik Steffens, sin Roburt Fulton ogr sin Georgr Stephenson, en Skjaldetil, der havde sin Goethe, sin Schiller, sin Byrom on her hjenme sin Skjaldekonge med en magtig Hird og en liunstens Tid, som havde sin Thorvaldsen.

Alt dette satte sit Præor pí den emerigre Præstediatter. Og i Nabopræstegirden i Drstrup havde hun et Kuld af Ungdomsvenner, hvorom Digtet „Ungdomsminder, tilegnede min Hanne Kaysen f. Koch" bærer Vidnesbyrd. Denne Veninde Johanne koch var ford i Døstrup I'ræstegârd den 19. August 1798, blev 30. Septhr. 1836 gift merl Skulelærer C. F. Kaysen og dode i Lmmerlev 1. Juni 1863.

I et Mindedigt om hendes Moder synger Anna bl. a.: "Nangen Lærd med tavs Beundring hørte, hvad Din Dømmekraft for Lyset førte.

- Mild som Kvinde - dog med mandig Ând kæk Du sprængte fordomsfulde Bånd!"

Tanken ledes derved hen pà en Slags Præsteskole eller Præstefriskole, som Faderen havde i sit Hus forst i Ảbenrá og siden i Brede, hvor han læste med unge Mænd, sà de kunle tage Studentereksamen. Blanlt de laan sấledes hjalp igennem var hans Hustrues Slægtninge, Præsterne Bonnichsen i Dybbal or Kier i Osterlysum. Det er da troligt nok, at Præstekonen ved Burdet of i leslige Timer nok ogsi har kunnet lade sit Lys skinne, ligesom Datteren har fået Ord for, at hun efter Händen hijalp til og det dygtignt. Hun elskede sit Modersmál og talte og skrev det smukt. Dette sidste fremgail ikke blot af liendes 
bigte, men ogsí ou makke endnu mere af hendes Breve. Men hun har Ord for, at hun ogsia med Færdighed kunde lase, slirive og tale Tysk og Fransk, ligesom hun ousia læste Latin.

1819 bler Kristjane Lautrup gift med J sr gen Simon Jessen, Præsten i Dagelol i den frisiske Marsk, lige over fur For. Han var en Bondeson fra Skovby, Vedsted Sogn ved IIaderslev or var fod 12. Maj 1790. Hans Fader var Galdumand Mads Jessen, Moderen var Maren Peder'sdatter, fıdt i Nabobyen Nastrup i Hoptrup Sogn. Muligvis har ousia han last hos Pristen i Brecle og siden studeret i Fiel. 1818 valgtes han til Prost i Dagebol, og han skildres som en høj, statelig, bredskuldret Mand, men med et molkt Blik, sâ Skrobeligheder ved hans Omgivelser let fuldt ham i Øjneue. Iristjane Lautrup, som bler hans Ilustru, havile ikke blot arvet sin Falers lyseblâ g!jne; men lende faldt Lyssiderne lettest i bjnene. Det er orsis sagt om heude, ligesom om hendes Veninde Johanne Koch, at hun ikke rigtion lassede for denne Verden, skgnt der er sal meget i hendes Liv, der virner om en ualmindeliy Iygtighed til at finde sig til rette i de vanskeligste Forlond on tage Hind i med. Hun harde ord for at vere sinuk. Iun rar ikke orer Mildelhojde, harde fintbyggede Lenmer, lavnesort Har, smm gik langt ned i Panden, hoj lingret Næse, fremstaende IIage, var rodmusset og lavde Ild i bjet. Hun rar ingen Modedame, men klædte sir efter sin egen Smag. Hendes Indlingshlomster var Rosen, Kixrminden og Immortellen.

Indeu Anna droy fra Fædreljemmet tik hun skatfet sign Billeder af sine For cldre og sin Bedstefader, den gamle Somand, som lâ sine samle Dage boede der i Brede 
Præstegård. Hans Hustru var den Gang doul, og hendes Stov genmes nu pá Bredle Kirkegard i samme Plet som Mandens, Sønnens og Srigerdatterens. Men hendes Billede har vi ikke. Bag pá Lorenz Lorenzens Billede stâr skrevet med ganmeldags Hândskifit: „1818, 20. April 82 År 2 Mineder". Præsten el fremstillet i Præstedragt med Bladkrave og Kallot. Bag på Billedet stir: „1818, 20 April 56 Âr 3 Máneder". Bå̆ på Prrestekonens Billede stâr: „23. April 1818, 69 Îr 4 Mancder grl." Billederne er fine, men L'dregningen af Prastekonens Alder stemmer ikke.

Pastor J. S. Jessen huede det ikke i Dagebøl, hvor han mente, der var kun et Element, da der kun var Dynd eller Skorpe for Jord, hverken Torveskær eller Skovhugst til Brændsel og intet brugeligt Drikkevand, nál det ikke hentedes langt borte eller opsamledes, nir det regnede. Fru Kristjane længtes ogea nordpai til de Danske; men Digterinden Anna trostede sig med Vesterhalvet og sang:

Tusinders Moder, Vugge og (irav, veldige Hav!

tankefuld ser jeg I/in vordeude Bolge, ile clen Svundne i Doden at følıre, tøruende rejse sig, svulpende slä, fråde, forgå.

Frihedens Datter! ej tîler Du Tvang! staulses Din Gang,

fængsles Du stuntom med isnentle Læuke, stakket kun Fjenden Din Velde kan kræenke.

Lænken. Du kaster med torduende Røst knust pả Din Iryst.

Stundom kun rejser Du Bulgen sâ hvid, venlig og blin

vugrger Du Mârgen pâ krusede Flade, leger med Strandurtens gyngrude Blade, bolger til Stranden de hvirle ug hli Muslinger små! 
Smiler Fuldmåuen fra Himmelen mild, baver dens Ild

trindt på Din Flade i hoppende Lner, snart som en Støtte jeg henrykt den skuer.

Dundrende hæver sig fjiernt og nær Andernes Hær.

Tidt har Du løst mig af Lipngselens Bånd, styrket min Änd!

Kommer den Time, der fia jeg kan drage atter mod elskede Norden tilhage, signende Dig vil jeg gribe min Stav, elskede Hav!

Den Time, hun dog sîledes ogsiá længtes efter, slonr, da i 1822 Manden blev kaldet til Sognepræst for Visby, som da hørte til Rile Stift, skondt det kun er en Milsvej nordvest for Tomder. Her var meset, der tiltalte hende, som gærne sysledte med Minder fra de gamle Dage. Drr var Kirken med sit gennembrudte Spir, som den siden har mistet, men som lium den Gang kunde se Fuldmånen kaste sine Straler igennem. Der var Kirkestolene „med Billeiler "f Helte". Der dvalede hun i Gravhvælvingen ved den fromme Provst Clausens Kiste. Trøjborg Slot oplivedes for hende ved Tanken om muntre Jagt i tæette Egeskov,

„lvor Bægret klang og Kæmpevisen gjalded og Kurens Horn fra Tinden mægtig skralded."

I Egekisten fandt hun der til Granskning Pergamentet med Vokssegl og Silkennor og med den blege Skrift, og der horte hun Sagn „om Rantzaus Jagt og Borgens hvide Frue". Hun glemte derfor ikke at leve $i$ sin egren Til og fryde sigr ved Guds Skabning omkring sig. Iun har Ord for at have anlagt Prantewilrdens Have, hvor hun frydede sig verl at se Brede slanke Kirkespir, der på en Gang mindede hende om Barndomshjemmet, hvor hun havde redet ranke pá Bedstefaders Knæ, mens han for- 
talte for hemde on Ansterdam, om Bjacret i Vestindien, der skurerles slat af skyerne, or om Hjemmet lisset, hvortil han snart fik Hjemlov, og hvor hun tidt og idelig længtes efter atter at modes med ham og med alle de hare, der gik forud. Af Bedstefaderen har loun i "Bedstefaders Minde" tewnet et siordeles tiltilende Billede, hvor han kunde fortalle, tage Del i Barnets Lege, i de Lidendes Nad, bede og lase for londe on sondayen i Bibelen.

„Du plsjed mangt et Âr det stulte IIav. til Søn ogr Maye sparsomt Brøl at hente I veulig By $\mathrm{Du}$ fandt Din stille Grav. hvis uberomte Navn Du for ej kendte.

I Fredens Bulig hos en elsket Son

Du nød Diu Kærligheds og Fromlieds Lan."

Han dorle kort efter Jul, 12. Januar 18:4. Ssmnekonen gik ogsit snart bort. Synet slog hende fejl og gik tabt; men hum var andsfrisk on fulute med til det sidste, indtil hun „rik til Hvile" en Simmerlay den 6. Juni 18:2". I Digtet "Moders Minde" har Datteren givet et smukt billede ogsa af hende.

Hun savnede hådt sin Moler, som sikkert har veret en karligr, kraftig men tillige nor myndig livincle, der ikke har reret raduild $\mathrm{i}$ en susever Vending. Derfor matte hun vere dobbelt glad ved at have fundet en trofast Radgiverinde i den forrige Vishy Prests Enle, Madam sch a mvogel, der med sin "werle Datter" lonede i sit Enkesnede lige over for Prastegardens l'ort. Og hun kunde nuk trange til gode Räd, som tidt var dỵe der i Prastegärden, hvor Mand ug Hustru sá lidet stemnede overens med hinanden. Inigterinden spillede smulit pa Harpe og sang dertil med klar og faengslende liost. () gesa nair hum talte 
var der hoj Maluklang i Røsten, og ved Harpen og Spinderoliken trostede hun sigr tidt, nâr det kneb hirdt; men det kunde ogsiá ske, at Harpen i længere Tid fik Lor at sta forstemt eller med hrustne Strænge, og vi kan da -kinne, hvilken Vederkvægelse hun kunde finde hos dlen ligestente Prasteenlie, ow at Hjærtet kunde hamre heftiot i hendes Bryst, nâr hun sả sin gamle Fader komme jagemule med sine „raske Brune“ omme verl Trojborg eller nár lum i sit Hjem favnede "den ensom gamle Fader", eller mar hun efterat vare smuttet over Gngen en Sommemorgen overraskerle Faderen i Barndomshjemmet.

Jen 12. Januar 1834 dokle I'ræsten P. H. Kjer i ()sterlygum. Samme År blev Prassten i Brede J. S. Jessen valgt til Sognejurst i sit Fondesogn Verlsted. Det kostede lans Hustru mange Târer at bryde op fra Visby, isar ved Tanken om den gamle Fader, der nu sad så ensom der ovre i Brede I'ræstegárl, skondt ham var bâde agtet og elsket af sine Sognefolk. Og Vennerne i Visby! og Blomsterne og Bierne og Haven, hun havile faet sat i slik:

.Selvplantet hanke merl de grroune Buer, min Summerlysu! hvor plejed jeg Dig ej! For forste Gang Du stär med modne Druer; uk for de modnes rejser jerr min Vej!

Eu fremmed Hând skal dem fra Stilken liryde, nu - grid de sinage vil og Hjærtet fryde."

Siledes sulker hun i sit „Farvel til Visby“. I Vedsted vall iklie nogen gammel Boro, om end Torning Slotsbakke ikke var langt af Led, og hun tiltaltes af Tanken on at finle Oldtidsminder i de gamle K a mpeh gje, hroraf rev var mange i Sognet. Immeryad, som ogsá findes der i signet, nærner hun iklie: men Nindet om "Hagenschills Nill" (Forræeleril har harmet hende, ligesom Tyskeriets 
Overgreb og overlegne Hån harmede hendes ægte danske Hjærte.

Hun vandt sig imidlertid snart Venner i Vedsted og blev afholdt som en deltagende Præstekone, der smilede med de Glade og græd med de Sorgfulde. Også i Vedsted syslede liun gærne om Sommeren i Præstegairdshaven. Under sin stolte Bøg, det „ægte danske Træ“, med dets stærke Tvillingsstamme og dets brede Løvtag havde hun sit Yndlingssæde. Der kunde hun se over Søen, hvor hun havde sin Båd, til Slukefter, hvor Maren Krog, Kromand Mortensens Hustru boede og var hendes bedste Veninde iblandt dem, der bød hende Trøst i mørke Kunmers Dage. Præsten led af en Sygdom („Hypochondri“), der voldte ham stadig Uro og ofte slog ud i Raseri. Øst for Præstegården, oppe i den sandige Kirkebakke, står der nogle små Grantræer, som han siges at have plantet ved Nattetid, når han ikke kunde sove. I Sognet pastios det, at hun skrev Prædikenerne, som han på Prædilkestolen læste op om Søndagen. Sikkert er det, at hun i al Fald til Tider har ført Kirkebogen. Hendes Håndskrift er kendelig nok.

Den 20. Januar 1840 var en Højtidsdag i hendes Faders Præstegård. Da var det 50 Ar siden den gamle Præst tiltrådte sit Præsteembede i ̊̊benri̊. I Kirkens Kor ved venstre Side af Altertavlen havde Sognets Folk ladet ophænge et oljemalet Billede af ham med gylden Underskuift: "Minde om Brede Menigheds Kjærlighed til sin 77 Aar gamle Præst Hr. Johan Christian Lauterup, opstillet paa hans 50 Aar's Embedsforelsesdag den 20. Juni 1840." Slægt og Venner fra Tinglev, ̊̊benrå, Østerlygum, Vedsted, Hejls osv, vare Deltagere i denne sjældne Fest med Hædersgaver til den Gamle, og Datteren skrev en Sang. 
Onitrent pí dette Tidspunkt mærkes det pî hendes Sang, at Holger Dankke vagner. Miske var det Prof. Flor, der havde nplaget hende? Fra nu af kommer der af og til i "Dannevirke“ "Hedeblomster af Anna" og Hlere af hendes Sange optegnes i skrevne Sanghogger. Silledes havde Sognefogrlen i Hammelev Nis Steffensen i sin Sangbog hendes Digt om Hesten, som hum kalder \&tling af en ædel Stamme; hun priser dens Skønhed, Tâlmodighed, Fyrighed, Styrke, Klogskab, Nemme, Blidhed og Mod.

Pî samme Naitle synger hun ousia on andre Dyr og levende Skabninger ogr pákalder Adelskabet i Mennesker. I sit Digt om Hunden priser hun dette Dyrs Troskab, Hengivenhed, Ảrvilgenhed og Mod, og Folk fandt stundom, at hun gik lovlig vidt i sin Omsor for Hunclen, livad enten hun nu kaldte dem Fillál, Linn, Sejr eller F'rejr.

Storken, Viben, Svalen, Sangfuglene og Smâfuglene ser hun på som venlige Budbringere, og hun kan neppe frikendes for lidt Overtro i den Retning, en Overtro, som hun i ovrigt delte med sit Folk i de Tiler. I vor Tid ser vel Overtroen noget amiderledes ud; men Overtro er der nok af selv hos Folk, som ynder at frikende sig selv for al Tro. Blandt „Hedehlomsterne“ i „Dannevirke“ er „Årstidlerne på Landet" et af de smulkkeste. Det stod i Bladet den 18. Decbr: 1841, og der skildres smukt de fire Ârstider: Vir, Sommer, Host or Vinter i Forhold til Naturen og den menneskelige Virksomhed:

$$
\begin{aligned}
& \text { "Lange Viuter er Hvilens Tid } \\
& \text { Vären yndig og Sommer blid, } \\
& \text { Hosst alvorlig. - Naturens Sơn } \\
& \text { finder stedse hver Ârstid skon." }
\end{aligned}
$$

1842 bler et mærkeligt Ar i Sunderjyllands Historie og i det "dankksindede Nordslesvigs". Men det gav oggki 
ell Vending i dets Digterindes. I Yedsted Kirkelsog har hun 17. Febr. indskreven sin Mand på Dødslisten og tilfrijet: „Han hlev valgt til Prest i Dagebol 1818. I Áret $18: 2$ blev han kaldet til Sogneprest i Visby i Ribe Stift. I Aret 1834 hlev han forflyttet der fra her til Menigheden. Han var siden 1819 gift med efterlevende Anna Christiane Latutrup, Datter af Præsten i Brede Johan Clhristian Lautrup. Han efterlader ingen Børn." Den 19. Febr. tillyste lnu Dordsfillet i „Damnevirke“ med Tilfojencle: „Legremlig svaghed var lians mangeiluige Ledwager i Livet. Fravarende Slixgt og Venner ville skanke mig deres stille Deltagelse. Nit Haih er henvendt til alle Enkers og Faderloses himmelske Herre." Pá Graren sydostliyn for Kirken har hun latlet henlagge en smuk, flad Grarsten.

Aret efter (Februar 1843) brod hun op fra Vedsted, hortil hun dog var blevet knyttet ved mange lizere Minder. Sit "Farvel til Vedsted" slutter hun sillodes:

"Jegr iler nu til Vestens flade Egn, hyor mangt at venligt Minde Hicertet fryiler, hvor Barnclonshjemmet stâr i skyłrgens Hegu, og gamle Fader mig velkomnen loyder.

Når Yåren vinker mildt til Liv og Lyst, nâr Rosen homstrer, Hqstens Nege liniłes, når Sneen hvirvler hvid om Laun og Kyst, Oaseu hist i Lyugen jeg vil mind.s."

Fun vendte altsát hjem til Bretle for at rære i Nærhoden af sin gitmle Fader. Men allerede 18. April 1843 skriver hun til sin kære Veninde i Slukefter. "Min Sundleed har $\mathrm{i}$ den sidste Tid været temmelig fist; men om jerr i Langden vil kunne udholde den urante Rolighed og Lvirksomhed, jeg her lever $i$, vil jo vise sig herefter. I 
Forstningen af mit Ophold her har jeg længtes meget, $o g$ det er af og til ikke ganske goolt endnu, endskondt jeg har al Grund til at være glad og vel tilfreds med mine Kâr... Jeg takker på det venligste Dem og alle Deres for alt mod mig og min Salige beviste Venskab, og for Deres Deltagelse og Tjenstvillighed imod nigr, sấ længe jex var i Deres Nærhed. For Fremtiten beder jegr om, at De vil beholde mig i venlig Erindring, som det bestandig fra min Side vil blive Tilfældet med Dem. Jeg glaerler mig til den Tid, da jeg en Gang igen kan besoge det kære Vedsted, men nair det vil kunne ske, kan jeg ikke hestemme, dng hâber jeg endnu i denne Sommer. Jeg håber også, at De og Deres kare Mand besøge mig her en Gang. Dersom De, kære Veninde! vilde gøre mig den Glæde en Gang ved Lejlighed at skrive nogle Iinier til mig, vilde De gore mig en stor Fornøjelse dermed. Jeg hwrer sil girne noget fra mine forrige $\mathrm{Hjem}$, or da De skriver să smukt, og med så megen Letherl, hâber jeg, at De en Gang vil opfylde denne Bøn. Jeg glæder mig til Sommer, ti da far jeg lidt at pusle med i Haven, og tor ikke bestandign sidde red nit Hjul eller Sytxj. De ved nok, at jey ikke meget ynder Stillesidden, men hellere tumler mig i Kokken og Kælder. Men her har jeg ikke Sligt at tage vare, og hor god man her er imod mig, falder Tiden mig ofte lang, som forr nassten aldrig var Tilfældet. Dog det giver sig vel med Tiden. Jeg beder Dem hilse Deres gode Moder og Mand på det venligste, iligemate alle svrige Venner og Bekendte, som De selv bedkt vil kunne hestemme. Nu onsker jeg Dem af mit Hjærte en glædelig Sommer, med sundhed og Forngjelse og Alt muligt Held. I Håb om, at De ogsa $i$ det fjærne 
beholder mig i venskabelig Erindring og under mange Hilsener fra min kære Anna er jeg

Deres hengivne Veninde

A. Christiane Jessen.

Hendes kære Anma er uden Trivl en Datterdatter af hendes Morbroder Jes Bonnichsen i Boldiksum, Datter af hendes Søskendebarn Enke Bonnichsen. Denne Anna var en Slægtning af Digterinden og blev siden gift med Gårdejer Nikolaj Ratenborg i Bedsted. Hende gav Digterinden sit Billede, på hvilket hun sidder klædt $i$ sine Yndlingsblomsters Farver, og efter hende har Frøken Petrine Baggesen, som var hos Digterinden $i$ hendes hoje Alderdom, arvet det.

Vi så, hun pønsede på at komme til Vedsted i Sommeren 1843. Muligvis har hun været med på Skamling den 18. Maj. Rimeligvis er det $\operatorname{dog}$, at hun først kom der 1844. At hendes Fætter var Præst i Hejls og Vejstrup, hvor Skamlingsbanken ligger, var ikke nogen Grund for hende til at komme der; ti han var ingen Ven af Skamlingsfesterne; men det ṃ̊̊ have været ved en af de to første Skamlingsfester, hun havde set Laurids Skau og var bleven stemt til Sang om ham:

„P̊̊ Skamlings Tind jeg så Dig første Gang,

Du kæklse Skovørn! med den klare Stemme;

Ha, den var dansk! - og Hjærtets Sejerssang,

som Vestens lille Sangfugl ej kan glemme.

Tør den vel ile fra sin fjærne Egn

til Østens Skov et stille-Kvad at synge

for Ørnen bag det lysegrønne Hegn,

og høres den bag talrig Fugleklynge."

Brevet sendte hum ham først med Skrivelse af 3. Juni 1846. Inden dette skete, var der imidlertid sket meget andet, som ikke må glemmes. Hun havde til Oehlen- 
schlæger skrevet et Digt og sendt ham det tillige med flere af hendes Digte:

"Store Skjald fra Akselstad!
tør jeg Harpens Strænge røre,
syuge Dig et kunstløst Iivad?
Ak, det vil ej nå Dit Ore!
0, hvor volder det mig Vé
Nordeus Brage ej at sé !“

Efter at hun smukt og xdelt har prist Skjaldekongens Digtning, vender hun sig med en vis Blufærdighed til sin egen:

„Kvindens hald er Flid og Fred, Rokken, Nål og Arnested.

Mangen Blomst dog spired frem i mit Hjærtes stille Have; skønt dog altid mest af dem, som der pryder tavse Grave: Alle blege, bly og små som den Plet de vokste på!

Turde dem jeg ofre Dig på det Alter Muser bygge! Måtte de udfolde sig i Din stolte Lavrbærskygge! Mig slig Fryd bestemtes ej, de må vandre Glemsels Vej.

Lad dem visne, lad dem do! Dig jeg forsst en Krans vil binde! Hjærtet gemmer mangt et Frø, hist måske det vil oprinde.

Hil Dig, bøje Skjald i Nord! god $\mathrm{Du}$ er, som $\mathrm{Du}$ er stor!"

Ochlenschlæger gjorde et Udvaly af de tilsendte Digte og lod Peter Ludrig Møller fá dem til Optagelse i sit Tidssknift „Gæa“ 1--3 (1845-47). Med Tidsskriftets første Bind modtog Digterinden folgende Brer: 
„Kybenhiwn, Norregale 46, den 27. Januar 1845.

Skomat jeg ikke har den Fre at kende Dem, eller vare kendt af Dem, håber jeg doğ, det vil ikke vare Iem alteles en Gitrle, livorledtes jeg er kommen i Besidilelse af de af Deres Digte, som findes optagne i den Samling, hvoraf jeg herved beder Den modtage et kxemplar. Det er nemlig Oellenschlager, som en Gang havde et Manuskript fra I)eres Händ til Gennemsyn, og som på eget An- og Tilsvar tillod mig for den af mig patænkte Samling at vælge, hvad der i hrjeste (xrad tiltalte mig. Hvis De altsá, som jeg dogn ikke háber, har noget imod det Skete, si mi jeg henskyde mig under Oehlenschlæger; han og ikke jeg er den Skyldige, og ham vil den arede Digterindes Vrede ikke for Tiden kunne nâ, da han endnu er i Paris.

Til Ovenstiende har jeg kun at tilføje min Udgivertak for de værdifulde Bidrag, hvormed De, vel uclen at vide det, har prydet min Årbog, - min Bson om Tilgivelse, fordi jeg, hindret på mangfoldige Måder, ikke fur nu har kunnet udfordige Exemplarer af Bogen til Provinserne, - sant det Onske, at De må have lige så megen Fornøjelse af $G æ a$, som jeg har havt ved at kunne gore det danske Publikum bekendt med en talentfuld Digterincle.

Med Højagtelse Deres ærbødige

P. L. Mnller."

S. T.

Malam A. Chr. Jessen.

Men inden Digterinden modtog dette, var der foregíet noget; som niitte gøre det klart, at hun havde andet i Sinde end udelukkende at hellige sig til Digterkunsten. Hun vilde ryre sig i „Køkken og Kælder". Ligesom Th. 
Thatrup ogr C. $\mathrm{H}$. Bredal i sin Tid vilde vare Bonder, saledes vilde hun nu være Bondekone. Det var i 1844 siges der, hum kørte ud med sin Faders Avlskarl Lorenz Ludvigisen som Kudsk. Øst for Brede Kirke ligger to mincle Garde, kaldet Storde. Inen ene var just fal. „Den Gard skulde $\mathrm{Du}$ købe, Lorenz!"“ siger Prcsteenken til Karlen. Ja, mente Karlen, bare jeg havile Pengene. „Nu Dn har ikke Pengene; men ser Du, Lorenz, jegr har P'engene, ogr i Ár er det Skularr, da má Ḱvinderne fri. Hvad mener Du, Lorenz, om vi to slog vore Pjalter sammen!" Ja süldan ontrent gik efter Sigende Frieriet til. Hvad Lorenz sagde, meldes ikke noget om; men vist or det, at hun og Karlem fik hinanden, skondt den gamle Fader blev ilde tilmode, da han hørte, hvad de havde for. Karlen var et godt wrligt Memeske, han stolede på og holdt meget af. Og Datteren, ja hun var jo hans Datter! Men hvorledes skulde dette i Længiten blive et lykkcligt Forhold. Hun kunde nu havt det så gorlt, levet af sin I'ension og sin sammensparede Formue; men hvad blev dot til med I'ensionen, nill hun atter giftede sig. Hun indrommerle, at der var stor Ulighed i Alder, livner og Dannelse; men hun mente, at Sindet var Hovedsagen, og da de var lige sindede, bodede dette på alle Vanskeligheder. Bonderne holdt meget af deres gamle Præst; men det rar iklie alle, der $\mathrm{i}$ dette tænkte som han, og der ymutedes endugsiai om, at han var nok ikke sả dansk, som de hidtil havdle ment. De tænkte vel som sâ: Bønderne er i Alminlelighed danske, mens kimhedsmondene og de Fornemme i Almindelighed ex tysksindede, og meget muligt, at dette var Hovedgrunden til, at hun vilde grifte sig ind i Bondestanden. 
Den 4. Juli 1845 dode hendes Fadel, mens Datteren lå i Febervildelsce on en Brandbyld lavile bragt hendes Liv i rare, sí det bler Lorenz, der, da hun kom lidt til sig selv, bragte hende Budskabet om Faderens Dod:

$$
\begin{aligned}
& \text { „Ej så jeg Døłlen løse Livets Bånd, } \\
& \text { modtog ej stumme Tryk af Faderlıând, } \\
& \text { ej bød jeg Dig den sidste Lædskedrik, } \\
& \text { og så det ej det milde Afskedsblik: } \\
& \text { men sukket har Du vist for mig i Lon, } \\
& \text { og liærlighedens Gud har hørt Din Bøn! }
\end{aligned}
$$

Sả samles vore trætte Ben en Gang, nâr Klokken synger Livets Svanesang. Hist samles Anderne i hellig Lyst, som faltes ej af noget jordisk Bryst! Der vil min høje Lovsang hæve sig til Gud, som slig en Fader skænkte mig."

Lt Par Máneder efter Faderens Dod var hun atter rask og giftede sig, og Madame Ludrigsen, som hum nu hed, havde det Ord på sig, at hun var dygtig til Altingr. Hvor fandt man en Honsegâd som hos hende, og sådanme Kalve! Disse passede hun selv, og hun viste i Gerning, at hun kunde mer end synge smukt om Dyrene. Hun kunde pleje dem, så det havde Skik. Lorenz var en flink Bonde. De passede deres Ting, satte Sterne efter Erne, der kom gode 'Tider for Bonderne, sa det gik frem for' dem, efterat de vel var liommen igennem oprorstiden. Folk længtes efter "Hedeblomsterne" i "Dannevirke“ og da der i 1845 var gâet lang Tid hen, uden at der havde været nogen, stod der i næunte Blad for 18. Novlur. 1845:

\section{Til Anna:}

Små IIedeblomster kommer

ej mere til vor $\emptyset$, den hele lange Sommer ej Dine Toner $1 \varnothing$. 
IIrorfur er Du så stille, hyorfor Din IIarpe stum? Da dremped tidt det vilde oprorte Hjærtes Skum.

Ssá mildt de Blomster smilte til alvorsfulde Blik.

Nar de ved Hjærtet hvilte, en Havbliksdrøm det fik.

0 , bind igen Buketter .or send dem hid til os, af denı vi Kranse fletter uvisuelig som Mos.

Als, i Noybr. 1845.

$* * * *$

Et Par Iger efter stor derefter Annas „Genswar :til cn Lubekendt pả Als" (Dannev. 6. Decbr. 1845):

„Jeg spanłt, min Mlage læste, nysgerrig hen jeg så, der ajner jeg: Til Anua! og Rokken gik i Stả. Eu sød Erindringstone igeunem Sjælen lød, mens stille Glædeslue mig maled Kinden rød.

Ukendte, Du som spørger fra Danmarks Paradis, hvi Anua tav sůlænge, modsat sin gamle Vis. $\mathrm{Ak}$, hun har Sorgen fristet, og tabt sin Fader kær, har skiftet Stand og Bolig og været Døden nær.

Nu smiler Glæden atter ved Mage, Dont og Stand, hun munter er som Fuglen og Fisk i solklart Vand! Ej tænkte hun, at Kvadet, hun uden Hensigt skrev, som Hedelærken kvidrer, af nogen savnet blev.

Men kan det nogen fryde, fra Dannevirkes Vold at hore Annas Stemme, da er den i Behold. Mer rjælden vil den lyde, mâske og mindre klar, da Tid og Vinterkulde dens Tone svækket har.

Men Ânden er den samme i Vinter som i Vår, det ærlige danske Hjærte udelt i Barmen slår! Ret barnligt det sig fryder, når ved Natureus Røst det stuudom Geuklang vækker i ædelt Dannerbryst.

Ukendte, Du som vakte mig af min lange Slum, ja gid jeg kunde dæmpe oprørte Hjærtes Skum! Hav Tak, fordi Du smilte til Hedeblomsten bly! måske en sådan svommer -snart til .Din $\mathfrak{0}$ påny." 
Det var altsâ ved Juletid 1845, hun slirev ovenstående Digt og vilde gerne fryde sine dauske Kamplæxller, gerne dampe de oprorte Hjærters Skum. Et halvt Ar senere var det, hun skrev sit Brev og sit Digrt til Laturids Skatt og fik folgende Svar:

Houst pr. Haderslev, den 26 . Juni 1846.

Kære Madame Ludvigsen!

Jegr ved ikke ret, horledes jex skal begynde, for at tilkendegive Dem min dybtfølte Tak for den lige sá store Udmarkelse, som opmuntrende Deltagelse, De har varet si god at vise mig, formedelst Skrivelse af 3. Juni, med indlagte hjærtelige og smukke Digt. I) verl ikke og kin ilike have nogen Forestilling om, hoor lykkcligt et 'Tidsjunkt Der'es venlige Brev ankom $\mathrm{i}$ - jes mener lykkeligt formedelst den Virkning, som det giorde lấ mit sind ti ellers ved Gud, at det ikke val en behagelig Tid for mig. Jeg var netop kommen hjem fra en longere Rejse, havde besogt Hovedstalen, det sylligre sjeclland, Falster, Lolland og derpa Landmandsforsamlingen. En Maengde Bekendtskaber havde jer naturligvis g.jort og erhvervet mange Oplysninger or Erfaringer; men jerg mat tilsta, at mange af dem var sure og bitre. Jo mere man lacrer den radsomme Swon og Ligegyldighed at kende, der er herskende overalt, desto mere overbevises man on, at det ikke alene er vort Slesvig, der skal frelkes fra national og altsa andelig Tilintetgørelse, men at selve Kongeriget lider af en indre Kræeftskale, der kun kan lages ved de mast remmemoribende, dybtgáende Reformer. At spise, drikke og sove godt og overalt gore sig Livet sia behageligt som mulint, - dette er Grundtanken i Flertallets Lestræbelser. For det Offentlige og for offentlige Personligheder 
interesserer man sìn kun for sá vidt, som der folger Lnaldeffekt, sa (犭jets Sans kan vorde tilfredsstillet; men hore vil man ikke. Sáledes har jeg i linngere Tid mærket og mærkede især på den sidste Rejse en stor Forundring on Misforngijelse med os herovre nor mel mig personlig, fordi man syntes, ,vi giorde ikke Noget.“ Det var Kinaldeffekten fra 184:-44 man sarnede, let var sålanne Ting, som f. Ex. mit beliendte Brev til Kongen, man vilde have. Disse Erfaringer havile gjort mig i hoj Grad mismodig, hvilket endnu forrarredes ved Skinsygens fæle Ånd, som jeg sporede tydelige og klare Beriser på i flere Yenners Falskhed, der næsten altid er værre end ábne og ærlige Fjencler. - Den clerover opstiede mismodige Stemning mildnedes imidlertid ved Deres venlige Brev, og jeg fik deri en Stadfæstelse pâ min gamle Mlening, at den rirkelige, uforanderlige og sande Varme næsten altid má soges og findes $\mathrm{i}$ det for Folelsen îlone Kivindehjzerte, medens Mandenes Varme som oftest har sin Grund i kold Beregning, og at en virkeljg varmitfolende Mand, hris Folel:e har sin Grund i ren og ublawdet Interesse for det Gode, er en stor Sjaldenhed. Men maxke netop dette horer til Naturens Orden.

Med inderlig Crlæde læser jeg "Annas" Vers i ..Dannevirke", og mere end en Gang har jeg havt i Sinde at skrive til Dem, ligesom jeg ogsá for læuge siden lar besluttet at besøge Dem i Deres Hjem, nir jer en Gang kommer pơ Deres Egns Enemærker. Jeg synes, det var si̊ ganske i sin Orden, at jeg hilste personlig på Dem, at dette Forset netop har været Årsag, at De endnu ikke nogen Sinde har fitet nogle Linier fra min Hînd. Hvis jeg imidlertid ikke af Deres Digte havde sporet, at De 
syntes at vare lykkelig, da rilde jeg ingenlunde have dvælet sí længe; ti det er mig en dræhende Tanke, at et Hjarte, der tildels bevarges af de selrsamme Folelser, som mit eget, i nogen Máde skulile vare lidende. $\mathrm{Nu}$ er jeg rolig i denne Henseende, sti meget mere, som Folk fra Deres Egn, som jeg nsije har spurgt om Dem, allerede i Efterỉet forsikrede, De havde det golt. - Nå Skahnen en Gang giver os Lejligher til at tale roligt sammen en Times Tir, skal jeg tillade mig at give Dem aklskillige rink med Hensyn til Deres Digte. Men lad os kun ret ofte se noget fra Dem; "Annas" Narn er lige sá vel set som vel kenclt. I Gair fik jeg lirev fra "len jydklke l'ige“ (Pouline Worm?), som ogsâ under Titlen skriver Vers $i$ „Dannevirke“. Hvis I)e i $\AA^{*}$ kommer til Skamlingsbanke, kunde jeg måske gøre vore to Digterinder bekendt med himanden. De vil ikke fortryde at tale med deune brave Pige nowle Øjeblikke; hun er damnet og follelsesfuld. Nok en Gang Tak for den smigrende Opmærksomlied, De har vist mig. Jeg vil vist aldrig tabe IIndet, sai læuge venlige Hjarter slar mig i Møde; ti i de bitreste sjeblikke sender Vorherre almindelig en slig trostende or opmuntrende Engel, hvis milde og blide Rost giver Styrke og Mod til ny og gavnlige Berlrifter. Men, kære Malame! jegr frygter, De overvurderer mine Kræfter; De stiller nig sikkert alt for højt. Forglem ikke, at jeg er fuclt og opdragen i Bondestanden og lever i den, så De er migr kærest, når De uden Omstandigheder taler ligre og rent ud til mig. Dette gør jeg jo til Dem, under Forudsætning af, at dette er Dem kærest. Lev vel og mindes med Venskab or Velvilje

Deres taknemligst forbundne

Laurids Skau. 
Den 2. Februar 1848 sliriver Digterinden til Veninden i Slukefter: ., Tor elskede lionge er sia urentet givet til Hvile, ja det var et meget sorgeligt Budskal, Burkkabet, om hans Hedenganan! Han var sâre elsket her i lignten, og Gul ved, hror meget han fortjente Folkets herlighed. Vort Hail) stâr nu til Frederik, or det vil med Herrens Hjælp ikke blive skuffet. On sig selv skriver hun: „Jegr er megret lykkelig nu, og jour siger dette, da jeg vód, at De tager sai varmt Del i min Sliæbne. Jegr har ikke altid med Sandherd kumnet sige dette; men nu stemmer Ijærtets Foleke overens merl Ordets Lyd, og jeg beder kun den Algode om Varighed. Det er uvist om min gmme Nage og jeg endnu en Tidlang ma nyle Samlivet; men (iucis Vilje ske... Nu gail vi jo allerede op ad Bakke, Dagene lienges og de lange Aftener er i Aftagende. Men er just mig sire behagelige, da de svinde sâ liurtig ved Forelasninger; som uulsat holdes hrer Aften af udsogte Bogrer. Da er jeg ret i mit Es, som min siger, or sailedes haber jeg, at det skal vedvare, indtil den k $y$ lige Nat en ('rang overrasker mig og fører mig efter en kort Slummer en Iysere Morgen imorle."

I samme Brev forenede hendes kære Mand sine Brmmer med hendes om, at de i Sturde matte modtage Veninden og liendes Mand som Gaster til Sommer. Der blev $i$ Summeren 1848 andet at truke på bille $\mathrm{i}$ Vedster $\operatorname{og} \mathrm{i}$ storde.

Til sin Slægtning Maler Hams Andreas Kier i logum skriver hun 23. Marts et langt Brev. Først vil hun troste Familien i sin Sorg over den lille P'eter Callewens Dod pai Lerskov, skriver om et kort Bessgy, hun har havt af Maleren og hans Broder, der ogsia havile sin unge Hustru 
med, Datter af Farver Peter Johannsen i Tinglev (17. Januar 17\%1-4. Febr. 1848), hvis Hustru var ell Datter af Bonden Jens Lautrup i Mellerup, Agerskov Sogn. Om Peter Johannsen skriver hun: Den ærværdige Svigerfader i Tinglev har da ogsá sit Lob fuldbragt, og der var vel fü, der kunde medtage sligt et hæderligt Eftermæle i Graven. Den varme, sande Menneskeven ulen Falskhed og Stolthed, javn og stille. Var der mange af hans Karakter, sá det anderledes ud i Verden nu om Stunder! Ellen savnede kun kort sin Fader. Hvorledes er det vel nu med den gode Farverenke? Tinglev er nu fremmed for mign, dette mign altid så kære Sted. Sả længre vi har boet her, var det altid vort Hâb, at den gode Farverfamilie en Gang - som bestemt val lovet - vilde have gladet os med et Besøg. Men dette slog fejl, og Doden har tilintetgjort etlıvert Háb derom. Yi vil hảhe, at Din kære Moders skrøbelighed rejser sig af Årstirlen og vil snart igen vige. Hun má ikke gå bort endnu. Hun har det jo vel efter Ønske or elskes or aytes af sin hele Omgivelse ogr lever midt i dens Sliwl. Din gode, kre Swater og Mand (på Lerskov) sendes de oprigtigste Hilsener og den mast levende Forsikring om vor lijarteliuste Deltagelse i Deres 'Tab! Du skrev, at Du var bange, at hun iklie kiulle kunne gennemgå den hårde Skole; men Mennesket kan, når det udfordres, udholde utrolig meset, ner enit Andre eller man selv tiltror sig... Var vi Eder meget nasmere, vi vilde da ofte samles $i$ vor simpelhed, som vi alle sa meget ynder, og udyyde vore Tanker og Folelser for hinanden. I de allerfleste Ting stemmer vore Synsnaider overens, og dette giver et behageligt Samliv. Hils Din kure Broder og hans smukke venlige Kone ret hjærtelip, 
og tak dem meget for den Glæde, de forrolate os ved deres Bessg. Det glæder os sii meget, at I kære Alle lever tilfredse og fornojede i himandens Nrrhed. Ikke mange Familier lever si̊ tæt forenede som I Suskende an Eders kare Moder.

Her skal hreranden til Regimentet i denne Tid. Gud ske Tak, at min elskede Mitnd har fitet sit Gardmandsjas, sia hiber jeg vist, at han er sikker. Den ene af de Svanstrup Mrend, som er gift med Fuldmægtig Lorensens Iatter, var ikke i nogen Rulle, men glemt at vare indfirt, han slap til nu no liev tagen til soldat uclen at maitte leje en Stedfortrwder eller kobe sig los fir nogen som helst Pengesum. Det ser temmelig sort ud pai den politiske Horizont i den sidste Tid. Gud give snart Fred i Landet. Derom beder vi jo Alle, enlıver ærlig Sjæl, rære sig tysk eller dansk. Det glæiler os, at de Hejlser befinder dem vel. Nâr jeg siger Familien i Hejls, undtager jeg Jærnstøberen (Bonnichsen i Haderslev); ti han er under al Kritik. Det er jo dog gorlt for Familien, at den conde, sragelige Fader lever hen sii lange. Ilden brænder bedst, sal længe den er samlet, siger man, og det er en Sandhed. Jeg hører yderst sjælden noget fra dem, sârelsom de fra os her. Men dog tagrer vi oprigtig Del i Alt, hwad der angair dem, og var forvisset un, at de gor det Samme. Er det Dig dog ikke mulig nu til Forâr eller lienger hen i Tiden at glæde os med et lidet Bessy. Kierere Ven lan ikke komme! Min kære, travle Mand plọjer daglig. Gud lad det fredelige Plovjærn ikke nogen Tid vige for Wlinkende Sabler! Men lat Enhver ngde sin beskedne Del i Fred og Ro, indtil Jorden modtager det Forkrienle- 
lige $i$ sit fredtelige Skod, orr det, som ingen I) od lkam tilintetgore, gair histhen $\mathrm{i}$ de Levendes Land.

Nu de krrligste Hilsener fra min ekkede L. til Dig, Din Noder og alle Dine, som ogsa fra mig, som for bestandiy i Sorg or Fryd, Liv og Dod, er Din uforanderlige. Yeninde

A. Christiane Ludvigsen.

Ien den blodige Krig kom, og Amnas Sange vidner om, at hun iklie vilde Fred for enlwer Pris. Med glødende IIarme over Oproset ng dets Hjælperes Vederstyggeligheder: og med en lige sí glosdende Taknemlighed og Hengivenhed til Kong Frederik or hans Hær, som i den blodigeliamp kæmpede på Liv og Død, skrev hun Kriggssange og. Sejerssange. Silledes bl. A.:

"Kæærfader lærte, at Slesvigs Land hed $S ø$ nderjyllaud! en Del af Dan. Ved denue Lare vi lolde vil, nár Uret driver sit Skændselsspil.

Tort første Ord, som fra Læben flod var Dansk! vi lytted på Morlerskød til danske Toner - vort Afskedsord det og skal blive pâ denne Jord.

Når vil Du bruse, Du stæerke Nord. at rense Vangen for Smerten stor? og drive Trigen fra $S \varnothing$ og Strand, som rælsomt skjuler vort elskte Land."

„0 Retfærds Gud, Du vil om Dana frede, og lyse for vor Drot i Tidens Morke! 0 giv ham Sindets Ro og Andens Styrke, og Fredens Glæder, efter Kampens Hede! Lad Folket gâ forædlet frem af Strid, og blive ærligdansk til evig Tid!" 


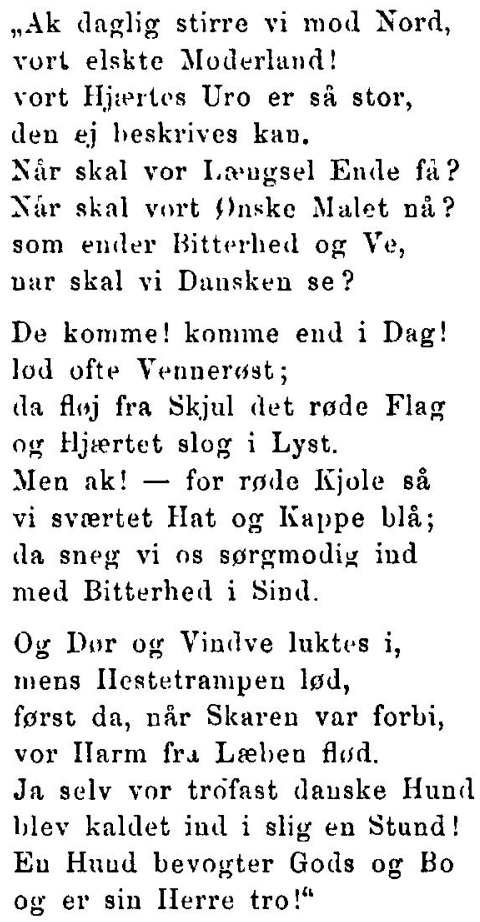

„Den danske Pige til den tapre Landsoldat", er skreven til Emil Hornemanns Melodi som Genswar til P. Fabers Kampsang.

„Krigssang for Sonderjylland" er en Vise på otte Vers.

Som Prove hidsæettes her det silste:

Skal Daner vige end en Stund

for Overmagt og Lumskheds Miner,

hun styrket vågner af sit Blund

en Phønix lig på Fædregrund

genfødes bun blandt Tidsruiner!

Skændselens Vej

valgte $\mathrm{Dn}$ ej!

- En Helteslægt vi lygge

i Nutidsgraves Skygge

med et Virke af Stâl Dig mod Rovlyst at betrygge! 
Til hendes Forældres Omgangsvenner hørte også Familien Wulff i Brede. Jens Wulff, Ridder af Dannebrog, var født 1. Maj 17r4 og boede i Brede som rig Kniplingshandler. Broderen Johan Andreas Wulff var fodt den 14. Marts 1780. Han var Elev af Pastor Lautrup, var sammen med Beyer fra Harris, som blev Præst i Tinglev, bleven forberedt til Studenter'eksamen. Kristjane Lautrup læste sammen med disse unge Mænd, som det kneb for at hamle op med hende. J. A. Wulff var bleven valgt til Sognepræst for Riis Menighed 22. Maj $1821 \mathrm{og}$ døde der den 24. Maj 1856 som Konsistorialråd. Til ham skrev Digterinden:

"0, ædle Mand! som ene stod, en Trofast blandt en troløs Skare, som trodsede med Retfærds Mod hvert nedrigt Kunstgreb, hver en Fare; Dit Fødeland, Din Konge tro, Din Løn er Agt og Sjælero.....

Ej vakled Du, og ej Du skjalv i Kamp mod Oprørs Afgrundsbøige; mildt viftende vil Fredens Alf Dit Fjed på Fremtidsbaneu følge. Og en Gang op fra Tågens Strand ledsage Dig til Lysets Land."

Under et Digt fra 1848: "Den danske Gardehusar" skriver hun: "Gardehusar af anden Escadron Nr. 27, som blev dødelig såret bragt til Rødekro, hror han døde, efterat have nedsablet syv af den Tannske Fiskare ved Mastrup på en Gang red et Overfald (red Hoptrup 7. Juni 1848). Han hviler på Kirkegården i Riis, hvor Dannemanden, Herr Pastor Wulff, har båret Omsorg for, at der sattes ham en Mindesten med en af ham forfrerdiget, passende Indskrift." Graven findes i Kirkegiordens nordvestre Hjørne tæt inden for Stenten. På den smukke, 
rodlige Granitsten findes qverst indhugget og malet et Dannebrogstlag, som en eller auden from Sjal dog ikke har kunnet nxgte sig den Lykke at sværte lidt i det ene Hjorne. Under Flaget stirr at læse: Husar Niel s Jen sen fra Calløe i Sjælland i anden Escadron af de kongelige Livhusarer. Falden dodlelig saret i Kampen mod de Tannske Friskarer den 7de - dod den 8de Juni 1848.

Landwmand, ser Du min Grav, si̊ meld det tilbage til Hjenmet, at jegr er falden i Kamp, tro min Konge mit Land."

Rigsarkivar A. D. Jøronensen har meddelt, at den faldne var Niels Jensen fra den lille $\emptyset$ Kallo i Guldborgsuncl. Om ham sang Anna:

Du stolte Helt! Oldkæmpen lig i Asers Land,

med Dødens Lyn Dit Glavind foer, syv Fjeuder bludig lí på Jord! da steg $\mathrm{Du}$, agte $\mathrm{S} \varnothing \mathrm{a}$ af Thor, til Hvilens Strand.

Fuld vord er, Edling! Din Bedrift, at tegnes op med Sagas Skrift, Du Hæder for Din Stand.

Jens Wulffis Svigerson Apotheker $\mathrm{N}$ ag el i Højer havde mattet bode for sin Troskab mod Konge og Fædreland i Fængsel hos (Oprsrerne. Lfter hans Hjemkomst skrev Auna:

$$
\begin{aligned}
& \text { "Som klare Gnist først farer frem } \\
& \text { ved Stålets Slag, } \\
& \text { sâ viser Troskalıs sedle Id } \\
& \text { sin Styrke først i Trængselstid, } \\
& \text { lig IIeltemod i hede Strid } \\
& \text { på Kampens Dag! } \\
& \text { Selv Pileskud fra Ondskabs Lejr } \\
& \text { Lefurdre kau det Godes Sejr } \\
& \text { i hellig Retfæerds Sag. }
\end{aligned}
$$

I denne Krig stod Frænde mod Frænde og Broder mod Broder, og under sâdanne hirr er Frænde ofte, onr 
ikke altid, Frænde rarst. I et af Annis Digte taler ,en dansk Soldat" sáledes til sin til Oprorerne overtrâlt Broder:

„Farvel min liroder! ja far evig rel!

Jeg iler hen for lietfierrls Sag at stride.

o Gud, at Du er vorden Skændsels Træl

og ej vil kæmpe ved IDin Broders Side!

at Brødre mgiles må pá Fædrekyst

at sende Kuglen mod hinaudens Bryst!

For Din forførte Sjal jeg bede vil, pá Jorden mâ vi bitre Fjender blive; og modes vi i Lampens vilde Spil en Kugle Broder kun kan Broder give. 0 , skáu mig Gud, for demue Jammer stor, - og lad os aldrig moiles her pá Jord!"

I Januar 1849 skrev hun et Digt til Ribe, hvoraf vi ser, hvad der følger af sig selv, at Ingemanns Romaner harr hort til de udvalgte slsrifter, hun kortede Tiden med i sit Hjem de lange Vinteraftener; men vi ser ogsá, at hun hâberle på og længtes efter den Dag, da „atter mod Syden en "Sejer" vil fare."

„Da vil han værne orn Snække og Plor

lygge med Lov

Landet, lig Volmer og skue med Glade, ældgamle Rihe! end Trofastheds Sæde!

- Stolt vil Da blomstre i Daunebrogs Ly, Mindernes By!"

Fra Brede er der ikke langt til Brons, livor den 22. Januar 1849 valmede Bonder blev slaerle af velorede slesvigholstenske Kirigsfolk. Men liun længtes utålmodig efter Cdlobet af Vábenstilstanden og efter at se "den tapre Landsoldat" drage i Syd fin den gamle Kongeby. Og hvor blev hun ilde tilmode, da Fjenden fik Udsættelse og det derefter gik sâ ikle til i Egernforde og ved Kolding. Da var det, hum en Dag kom hajt lutliencle ind 
i Døstrup Prastegaird til sin gamle trofaste Ven Prorst Gabriel linch (folt 3. Aur. 1r4\%, dod 16. Olithr. 1865) som en Skiblorudden, og det holdt hárdt for Prorsten atter at fả liende bragt Skiden flot. Siden skiev hun ,Den sonderjydske Bondes Sang“, hwori hum dommer mildere om de projisike og orrige tyske Krigsfolls, som var drerne herind langt bort fra Fædreland, Foldested, Forrddre, Born on Mage for at tjene Forredere, og udbrod:
"Gid suart de vende hjem igen;
men hine Skændselsknægte,
der lobe bort fra Bog oo Pen
for syndig Sag at fægte,
der lyve prale, true slĩ, tilfoje Skam or Skade,
de Danmarks Fjender hedde må,
og dem må Bunden hade."

Og vor Moders equne utaknemlige Sonner, som lomner hende med Had "g Hản! Den ha: hum alt for lange ladet râde sig sclv og ikke avet dem i Tide. Men bliver Ioder Danmark rred til Gilvns, hijelper ingen ,kære Iorjil ${ }^{*}$, si vil de komme til at bode for den Frælilhed, hvormed de har lianet liver dansk, ja selve Kongen. Var deres Stormstiger ikke for korte, stormede de rel Himlen med; men nu mí de lade det være or se at komme over, hvor Gærdet er lavest. Imidlertid kom Fredericiaslaget, og Piben tik en anden Lyd.

Si blev der atter Vibenhvile, under hrilken Tillisch ng Eulenburg stod for Styret i Sonderjylland med en Engelskmand Lord Woodhouse som Opmanu, medens projsiske Tropper skulde stâ dem til Tjeneste syd for FlensborgTonderlinien og srensk-norske nord for denne Linie. Ogr Anna hilsede "de skandinariske firigere ved deres Ankomst": 
„Hurra for Svensken, Fredens tro Beskytter, som när Vildtysken fræk sin Næve kuytter, med Fynd og Klem den Rasende vil ave, som ypper Kiv i egen Moders Have.

Hurra! Hurra!

Anna var ikke Slesviger! Iun var Sunderjyde, hun var Dansk, og frem for Alt, folkelig talt, nu Skandinav, og når hun tilsidst skal sige, hvad hun vilde, da syngei hun:

Høit vilde jeg synge for Trillingestammen:

i Medgang og Modgang at holde tilsammen!

Lig Fyrren og Egen, i Skovene delt,

i Kampen mod Bølgen de udgør et helt!

Sa kom 1850 med de voldsomme Torn ved Isted, Mysunde og Frederikstad.

Den 18. Marts 1850 havde hun skrevet til Veninden i Slukefter: "Allerkæreste Veninile! Mange Gange har jeg havt i Sinde at șrive til Dem; men nu må det endelig blive til Alvor. Ln særegen Omstændighed fremskynder mit Forsats Udforelse, nemlig den, at jeg i lang Tid næsten et Par Gangre ugentlig i meget levencle Dromme er hos Dem. Snart vandrer vi sammen i smulke Egne, snart er jeg hos Dem i I)eres Hjem osv. Jeg har ofte talt med min Mand derom; ti det har været næsten pafaldende ofte. Jeg iler derfor at skrive nogle Ord, og háber, at De, nâl De har Tid, melder mig Deres Befindende, at jeg dog kan forvisses om, at De og Deres kiere befinder Dem, som vi sä garne onsker det. 'Tro ikke, min Bedste, at jeg har grlemt Dem eller holder mindre af Dem, fordi jeg aldrig har ladet se Tegn derplia i sál lantr Tid! nej, min Veninde! Jeg glemmer Dem aldrig. De har en Plads i mit Hjærte, som i Liv og Død er Deres! Men de onde Forargelsens Ticler har ogsi virket i den Retning, at jeg ikke har følt 
Lyst til Nogenting. Ja jeg kan sige, at de to sidste Âr har havt en sadan Virkning pi bâde Legeme og Sjæl, så jeg aldrig mer ret vil forvinde det. De ZErgrelser, man har måttet døje og endnu daglig er udsal for, søger Sjælens Grund pả enhver Trofast. Imidlertid haiher vi snart. at fi̊ et godt Udfald af Hovedsagen, og så jæunes der Meget, men udslettes vil det ikke i min Tid. En Anstxxlssten for vort Velbefindende findes her især, og som sandsynlig vil blive liggende; nærmere Forklaring herover mundtlig. Jeg kunde ellers nu leve så formojet ved min kære Mands Side, og uden store Sorger for Fremtiden. Men Noget må der altid være i Vejen, ellers var det alt for godt for migr nu. Tor vi ikke i næste Sommer vente et Besøg af Dem og Deres kære! Deres gode Mand holder vi også sâ merret af; jeg glemmer aldrig, hvilken god og tjenstvilliy Nabo, han var, da jeg endnu levede i Nærheden af Dem. Og jeg er Dem Berge bestandig taknemlig derfor. En rod, tro Nabo er bedre end slægt og Venner, det mi jeg af Erfaring saule. Gid vi havde Dem i Nærheden igen! men vore Onsker nytter lidet $i$ denne forvildede Verden. Vi er så fast bundne til Pletten vod det stakkels Legreme, der fangsler Ånden, og der er ofte så mange Omstandigheder vel dets Flytning, så man må grue derfor; ellers kom jeg meget ofte til Dem. Kuncle De se mig med legemlige o jne, hver Gang min Tanke iler til Dem, vilde det gâ tidt på. Når nu Víren kommer, vil jeg ret ofte drømme mig tilbage i de kære Træers Skygge, nede ved Soen, or titte gennem Løret op til Deres Bolig, som jeğ sî mangen Gang har gjort. O, de var mig si̊ kære, disse gamle Træer, hvis Grene næsten berorte Vandet! Sin elskede L. har vel plantet en Del, og de vokser ogsa 
goolt; men inden de el så vidt, at de kan optage mig $\mathrm{i}$ deres Sliggre, er jeg vistnok længst i en anden Verden. Efter de ganle Kompehgje langes jeg ofte, jeg har der havt sia mangen skon Time red at liendromme mig $i$ svundne Tirler. Jeg skal en Gang, nä jeg sender Dem nogle Billeter, hoslagge et lidet Digt: min Afsked fra Vedsted, som jeg vist tror vil behage Dem, ikke for sin Skønheds Skyld, men fordi denne Tid ogsá endnu vist mindes af Dem. Nâr vi en Gang fár Fred, har jeg i Sinde at udgive henimod et Par liundrede Smidinte til Bedste for vore danske Sarede. Ellers var det vist aldrig sket; men kunde jẹ pâ denne Måde gavne lidet, sä synes jeg, at det er min Pligt, og har, opfordret dertil af flere, givet mit Samtyklie. - Matte jegr vel besrare Dem med Indlagtes Bessirgelse sâ snart som muligt. Det er angâende Aviserne, som vi i hele lirigens Tid ilkle har havt, men nu gærne ynsker jgen... Min gode Mand hilser Dem og Deres kære lijærtelig ngr beder med mig om Deres Besog i tilstundende Sommer! Gid vi da tales med Glade, hris det er Guds Vilje, og gid Fredens Genius daler smilende ned til vort elskerle Land forinden den Tid... Inder mange kærlige Hilsener on wnsker for Deres Alles Vel, er jeg

Deres Deni trofast elskende

A. Christiane Ludrigsen."

Efter Frerlsslutningen og Slesvig-Holstenernes ogr deres Hjælperes Afvahning skrev hun sin , (ilade ovel Freden."

Synger, Småfugle! uu Sommer i By, jul,ler fra løvrige Kvist.

Hører I Susen og Vajen i Sky?

Ser I min Dannelorog hist?

Suehvid som Liljen, som Rosen så rod

stråler den nyfødt i Vårsolens Glød! 
Den 5. Juli 1851 skiver hun til Madame A. E. Callesen på Lerskov: fore liwre Venner Alle! Den hjærteligste Tilk for sidst beriste ciodhed! Skmnit Vejrliget i det hele jo var måleligt, imedens vi var hos Eler, så mi vi dog henregne den linserejee til en af de glcedeligste og behageligste, ri siden ri bo her, har havt! Hor kan man andet end fole sig fornojet, nâr man finder slig Velvilje, Uerennyttighed og forekmmmende Godlhed, som vi fandt hos Eder, I kare! I er mine eneste Slagtninge, de Andre - de fir i Vejstrup undtanne - er migr aldeles fremmede og ligegyldige. Min Mand fuler sig lige sả lykkelig i Eders Selskab som jear, or fir ham mange venlige Hilsener og 'Taksigelser til Eder' Alle, i Lerskov org Lygum! Jeg havde skrevet for, hris jeg havde liumnet fí Kniplingerne straks. Der er nu ikke nar sit mitnge, der knipler, som for, da Ferdinand Wulff tager nosten alle Piger i Beslag til sit Yareri med at ræve, or de Ingste, som ellers kniplede, til at sipole. Om Du er tilfreds med dem, ved jeg ikke, de har kostet 5 Mk. Alen, men burde have været smuklere og spidkere takket; men der var ingen mere passelige at fi, kære Lugenia! Jeg er meget lykkelig med Dine Oste, og takker Dig hijertelig for Din Godhed. Dine Blomster vokser godt, og jegr skal sørge for at plante Dig nogle smukke her, som Du ved Lejlighed skal fi.

Lille Misse skikker sig vel og er bleven vor Kæledægye. At hun er fra Lerskov er heller ikke til Skade for hende. - Hvorlecles er det mel Din goule Moder, kære Geniat? og nir kommer Din Broder op til os? I denne Tid ønsker vi det ikke, da vi er i den, for os meget travle Hohøst, da L. er aldrig hjemme, og det går i Hastværk fra Morgen til Aften, især nilr man, som i År, 
har Mistro til Vejrliget. Vi har nemlig vort meste Ho ved Åen, og kommer der da megen hegn, kan det hele flyde bort, eller må bjærges og ophares med stor Irøje.

Her er Kornhosten ilike at regne imod Hohosten. Hos Eiler er det vel omvendt. I)et var Skade, at vi, da vi var hos Eder, ikke for Vejrets skyld kunde komme lidt omkring og se os om. Sksmdt vi moretle os overmide vel inde, så havde det dog været ret behageligrt at se Træplantningen og de nærmeste Omgivelser. Vi havde ellers en lykkelig Hjemrejse, vi befandt os vel og fandt Alt vel hjemme.

6. Juli. I Dag er det Synday, orr jeg har nu Lejlighed til at fuldende. Det er Eftermidlan, on nylig rejste vor P'iges to Brodre, Morbroder of kin til her fra, som just kom hertil til Middag. Den ene Broder, som er Styrmand og har varet rundt omkring $i$ den store, vildsomme Verden, har hun ikke set i ti Ar, og nu talte de kun sammen et Par Timer. Det går să lojerligt og ulige til i denne vildsomme Verden. Somme tumler omkring fra det ene Land til det amlet, ja fra den eve Verdensdel til den anden, og andre forlader neppe den Tue, hvor de sấ Lyset første Gang. Dog den længste og vigtigste Rejse må vi alle gøre til Slut, Rejsen til den anden Verden, og. der vil vel mange, som her var Kaphtain, komme til at fare for Svabergast, og omvendt.

I denne Tid er Ferd. Wulff i London at beskue den uhyre Udstilling, og Hochberg har sendt Kniplinger derover, som findes der blandt de utallige beundringsværdige Kunstværker fra alle Lvropas Lande og lyne og af alle mulige og tænkelige Slags. Jeg synes, at man kunde blive tosset i Hovedet $0 \mathrm{~g}$ iklie se Skoven for bare 
Trreer. Jeg rejser ogsit, men kun om Natten, og da synes Søvnens Engel red smnkke Dımmebilleder, at ville holde mig skadeslos for min bestandige Drælen pi̊ en og samme I'let, hror så sire lidet er for ojet.

Jegr må endnu melde Dig, at min faderlige Ven, den gamle gorle Pastor Holn i Emmerlev, der hvor vi en Gang var, og havde den fiele Hjemrejse i Mørke -- den 10. Juni pludkelig uden Sygdom, er giiet heden. Han var mig en anden Farler, og slirev mig et IBrev - et helt Ark, fa Dage for sin Dsrl, som jec just vilde besvaret, da Budskabet om hans Dod kom.

Nâr I en Gang făr Lejlighed, s̊a hỉber vi at se nogle Linier fra Eder, lwvorefter vi langes. Vi tænker pâ og taler tidt om Eder ng gode Mutter i Lygum. Gid vi atter en Giang ses suncle og glade lige som sidst. Man ved ikke, nlår man siger hinanden Farvel pá længere Tir, om det măke er for sidste Gang for dette Liv; men hrordan det end er, sâ ved ri, at der er et andet or bedre, hvor vi en Gang vil kunne genhilse hinanden efter den kummerfulde Livssejlads Inin kærligre Moder vil Du bringe de liærligste Hilsener og Taksigelser fra os begge for hendes Godhed imod os, kare Eugenia! Jeg tankel tilt med Forngjelse på Dine ssole Børn, hvor de dog er væure og lan synge og dause. Slig lunslign Lystighted er den mindst bekostelige og i Grumden den bedste. Hils Dine kære Smapiger ret meget fra mig. Min Mand savelsom jeg hilser Din gode Mand på det hjærteligste og takker ham for al hevist Venlighed imod os. Gid det ikike varer for lienge, inden vi ser Eder hos os her.

I Forgårs var det seks År siden min Fader gik til de Saliges Boliger. Han var lykkelig, at han ikke op- 
levede Krigens Forargelser, og să de mange skændige Affald fra Pligt og El, som vi Andre har voret Vilne til! Nu má jeg vel slutte og onske Eder Allesammen i nin Mands og mit Navn en glkedelig Sommer, god Sundhed og fulde Lader. Over Diw, min sode Eugenia! glwdede jeg mig især, ti jeg har aldrig set Dig mere rask og munter end denne Gang. Siledes kin Sorg forvandles til Glixder og det er i Grunden altid Tilfældet, nír vi kin kan med Tálmodighed oppebie Hjellens Time af Guds Händ. Farvel, I kære Allesammen.

Eders uforanderlig trofaste A. Christiane Ludvigsen.

Forst i Året 1852 blev „Markblomster af A nna “ tilsendt Subskibenterne. Hun havde forst sendt dem orer til Ingemann, bedt ham om at gennemse dem og skrive en Fortale til dem. Hun fik derefter folgende to Breve: Suris, den 30. Juni 1851.

Jeg har for nogle Dage siden modtanet de mig tilsendte to handskrevne Hefter tillige med Deres forckommende Skrivelser af 2. og 11. Juni, og jer vil ikke opsactte foreløbjg, med min venligste Tak for de velvillige Ytringer, at meddele Dem den Anskuelse, jeg allerede ved at kave last $\mathrm{i}$ begge Hefter ontrent en tredive Digte er kommen til angâende disse Digtes Forhold til det Hjærte og den And, hvoraf de er udsprungne og til Boghandelen og den Læseverden, hwor De onsker dem udbrelte.

Digtene rober en ædel kvindelig Natur, der med inderlig. Kserlighed til det Gode og :Skonne og med aben Sans for Naturen har tilegrnet sion al den Damelse og æasthetisk 
Ldvikling, et fortroligt Bekendtskab med vor poetiske Literatur mi medfore, on med et uniskendeligt Talent til at ultale sine Tanker, Foleker or Stemninger i et ualnindeligt regelret Sprog og i de Ualtryk og Former, ler gennem liunstpoesien er blerne garngse og ligesom stiende. Fremstillingen synes mig i Almindelighed at beræcre sig pa Grænsen mellem Veltalenhed og Lyrik, som i Tyskland i l'erioden efter Schiller og i Ianmark efter Opsringet ved Frald og efter liunstpoesiens ny Retninger i dette Århundrede. Slige Frembringelser af en Tidsalders æstletiske Damnelse er talende Vidneshyrd om Kunstpoesiens Indgribelser i Livet og derfor altid agtværdige, allerhelst, nair de, som her, sibner Indblikket i et fromt ong adelt Sind i en fredrelandsk, begejstret Sjæl og i et elskvardigt Familieliv, men hror den af Poesien let modtagelige Ân dog ikke egentlig kan siges at bryle sig en ny lane ogr fremtrede som Barer af ny eller hidtil upáantede Ideer og Livsanskuelser i Sandhedens ogr Sksnhedens Tjeneste - der vil altid selv de heldigste Udgydlelser af And og Hjerte vanskelig tildrage sig almindelig Opmærlksomhed or derfor sta $i$ et misligt Forhold silvel til Boghamitelen :om til den stsrre Læseverden.

Jeg har oftere været anmodet on ved Fortaler eller Indlerlninger at indfore yngre Forfattere i Literaturen, som det kaldes, men jeg har altid væorret mig derved. Det strider mod min Anskuelse af den enkelte Skribents Selvvurdering og formentlige Forhold til Pulsikum at fremtræde som andelig Formynder eller med en Beskyttermine, der naesten kun altid fremkalder Opposition netop mod den sillerles af en selvgjort Myndigher Fremstillede. Dersom De onsker det, skal jeg derimod gerne tilskrive min 
Forlægrger, Cniversitetsboghandler Reitzel i Kobenhavn, at Je vil tilbyde ham Manuskript til Forlag, og sige ham, hvad jeg oprigtig mener om dets Værd; men jeg fortulser et Afslag af Boghandlergrunde. Lyrik er neton, hvad der nu allermindst gælder pi̊ Bogmarkedet. Når jeg enclnu en fjorten Dages Tid må beholde Hândskriftet, skal jeg helt gennemlæse det og meddele Dem, livad jeg fremdeles mâtte fincle at bemærke. Hav den ciodhed forinclen med et Par Ord at lade mig vide, om jeg forelobig skal skrive til Reitzel derom. Et Udvalg af Samlngen om muligt fin eget Forlag, vilde jeg anse for hensigtsmassigst.

Hjartelig Tak for det venlige Digt til migr og den levende, kærlige Opfattelse af mine historiske Bllleder, som jeg hajlig påskønner.

Jeg forbliver med megen Hajagrtelse

Deres liengivne

B. S. Ingem an $n$.

Sor', den 20. Juli 1851.

I Dag moltogr jeg Deres Skrivelse af \&. d. M 0 geg vil ikke opswtte at meddele Dem, hvad jex endnu har at bemarke on de indsendte Sunge og Deres mulive Udgivelke, inden jeg med næste Pakkepost (den 22.) tilbagesender Dem begrge Hefter. Dersom De bestemmer Dem til at udgive et Udvalg af Sangene, vilde jeg forst rahde Dem til et Gennemsyn af dem alle, og hris l)e billiger mine lemarkninger, da med mulige Udeladelser, Forkorteker

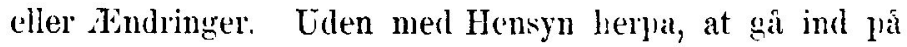
det Enkelte, skal jeg lolot tillade mir i Almindelighed at paipege, hvad jeg henstiller til Deres Selvhitili ved (ienntmsynet og Covalget at tage i Betragtning.

Da en stor Del af disse Sange indeholder Stemninger, 
Folelser og Tanker, som i forskellige Former udtrykker Deres Kirlighed til Naturen, Landlivet, Fodrelandet, til agtverdige Frænder og Venner, Deres Deltagelse for Poesien on dens Dyrkcre, Deres Follelse af Fjendetryk on Deres Háb og Tillid til vore brave Krigere - Deres fromme, kristelige Betragtning af Livet, Lssden og Evighedell sil mener jëg, at de kunde træeffe et Udvalg af hvad der cjendommeligst betegner disse ofte genkommende Stemninger, hvorved den hele Samling vist vilde sammensmelte til en 5-6 Ark, og dil vilde Bekostningen ved deres L'dgivelse næupe overstige $50 \mathrm{Rd}$., hvoraf styrste Delen vel mâtte antages at kumne indkomme ved deres Forliandling.

I hver enkelt Sang vilde jegr râde til at udelade alle de stanende Former og alt for tidt gentagne Billeder af Kiunstpoesien (f. Ex. Støvets børn, Øje, Mal etc, Gravens (iemme, Naturens Skod, Jordens Muld - Billederne om Harpen, om Juserne - si vel de græske som de oldnordiske Mythebilleder (f. Ex. Sangen om Fenris og Nr. 8:3). Liun i en episk eller dramatisk P'oesi, der fremstiller den mythiske Tids Helte, som ultalende Deres egen Religion or Liwsanskuelke, synes Mytlebillederne mig naturlige; men ikke i nyere Lyrik, der liun skal udtale, hvad vi selv i Liv og Tro tilegner os. Sâ kşnt og rigtigt Oelılenschlæger har anskueligrjort Mytherne i sin dramatiske og episke Poesi, lige să urigtigt mener jeg han anvenolte Mytherne sin Lyrik (narnlig i hans Mindedigt over Christian den Ottende, hvori ham lader alle Nordens hedenske (iuder modtage ham). Endnu mere stoder det mig, hror hedenske og kristelige Billeder i det samme Digt sammenblandes. Selv Skæbnen i sin hedenske Butydning spiller mig for vigtix en Rolle $i$ mange af Jeres frommeste Digte. - 
Mangfoldige Billeder og Lidtryk kumne bide være rigtige og oprindelig smukle, men er dog for ofte gentagne til at bruges fia $11 y$, f. Ex. ,at vandre Livets tornefulde Sti“ (pag. 107), og nir et Billede skal give en hel Forestilling, má det ikike blandes med andre, f. Fx. N1. 8: "Lad Hytten synke ned i stille Blund, som ofte trykkes med sin tunge Byrde."

Deres Versformer er i Almindelighed meget regelrette og Rimene kraftige. Caggtet De kalder disse Sange Naturens Born, landlige, simple Sange, kunne de dog ingenlunde henregnes til Naturpoesien - de er ähenhart Frugter af Dannelse. Det er den fromme, adelt dannede Prastedatter, der udtaler sig i Kunstpoesiens kun alt for gængse Sprog og Former.

På de ylle Sprogformer er der, som sagt, ikke noget at udsætte; men den rent lyriske Fremstillingsform mà ofte vige for et alt for stackt Hang til at falde ud i heflexion og almindelig lietragtning. Enkelte Naturbeskrirelser fincler jeg heldigst, og nveralt, nâ det er en virkelig Genstand eller en Person der skildres, f. Ex. Digtene om Deres Fader ng Bedstefiuder tiltaler det mig mest, som Alt, hvid man kan se, er virkelig oplevet.

Tilgiv migr nu, hvis jeg ved disse Bemærkninger volder Dem nogen Forstemthed eller Besvær ved Omarbejdelse og Endring, eller Mismodighed ved Selvforkastelse af, hvad De maiske for har fundet heldigere - men om De derved forkastede den halve Samling, og, med Losrivelse frat det alt for gængse kunstpoetiske Sprog, fandt ny ejendommeline Former for Deres Naturs Poesi -- var det en Skat, jeg ved lidt at fortrædige Dem, havde bragt Dem til at oplede i Deres egen indelige Mark og Have. 
Til venlig Erindring sender jeg Dem nogle af mine allersimpleste Smádinte, som jeg netop for deres Simpelhed sxtter mest Pris par, or som jey havde snsket at skrive enthu simplere.

Ieres hengivne

\section{B. S. Ingeman $n$.}

De tilsendte Smadligte ral Ingemanns Morgen- og Aftensange, sat i Musik af Weyse. Foran i det indbundne Exemplar har han skrevet:

"Til I'oe.iens adle Veninde og stille fromme Dyrkerinde Anna Christiane Ludvigsen, fodt Lauterup.

Soso, i Juli 1851.

Til venlig Erindring

fia

Forfatteren."

Det srnes iklie at rære megret, hun overkom eller tik sind til at fit rettet. Henimod Jul skrev hun til Yeninden (Madame Mortensen) i Slukefter et Brev, hrori hun blandt andet ogs:i omtaler Udgivelsen af sine Sange.

Den 14. Iechr. 1851 har vi atter et Brev fra hende til Noulame Mortensen i Slukefter, hvori hun skriver, at hun forgres havde rentet Veninden og hendes Familie om Sommeren, og at hun, da hun i Pinsen var i Lerskov or Lygum med Langsel sa hen til den Kant, hvor Vedsted lignger, men umulig kunde grore en Afstikker derhen. Ret lijertelig længes jeg efter, vedhliver hun sii, at tale mundtlig med Dem, og vil Gud, ma le love mig til Sommer at hesgge os. Vi har jo nu, Gudkketak! Fred, og det er et stort Gode! Da mine Sange - $i$ det mindste en Del af dem - nu bliver trykt lios Redalktor Kastrup i Flensborg, háber jeg, nar jegr skriver til Dem igen, at kunne have den Glæde at sende Dem et Exemplar til venlig. 
Erindring om mig. Nåske vil jeg da lange efter min Død på denne Vide åndelig kunne underholde mig med Dem, og De vil skænke mig en kærlig Tanke og mindes rlen Tid, da vi var hinanden nær.

Tak, min kære, for Deres venlige Digt til mig. Det gemmes blandt mine kæreste Minder og vil, sålænge jeg lever, være et talende Bevis på Deres venlige Sindelag imod mig. Ret glædelig overraskende var mig sidste Sommer P. Jørgensens kærkomne men kun alt for korte Besøg. Min gode Mand beder Dem, tillige med mig, at hilse og takke ham derfor og bede ham om Gentagelse for længere Tid. Denne ærede Ven fortalte os adskilligt om Forholdene i Deres Sogn, som vi meget beklager; men desværre må jeg sige Dem, at det ikke er bedre her med Hensyn til vor tyske Præst, men måske endnu værre. Ikke kan jeg betro Papiret noget af det Meget, jeg ellers folte Trang til at fortælle Dem, og vil derfor afbryde. Vi har det Håb, at alle slige Misforhold herefter; når de rigtigere Ting først er afgjorte, vil efter Hinden vorde jævnede, og må indtil så længe være tålmodige. Vor Sundhed har i det sidste $\AA$ r været temmelig god, og vi kan ikke noksom takke Gud for alt det Gode, han giver os. Jeg er ret lykkelig nu, kære Veninde, og vil Gud bevare mig for Sygdom, så synes det, at mit Efterår vil frembringe flere og skønnere Blomster end mit Forår og Sommer. Matte jeg kun altid med inderlig Taknemlighed erkende denne Nåde... Det glæder os ret at erfare, at vor gode Ven B. Møller (Præstegirdsforpagteren) er en så tro dansksindet Nabo. Han el os desårsag dobbelt agtværdjg. Men vi beklage i si̊ Fald hans Stilling, da vi har hørt, at Pastor Jensen er af modsat Tænkemide. 
Jey má tilstá med en Slesvigholstener kunde jer ikke udholde at være under Tag, uden at det vilde give Ihd, som nar to harde Stene slás mod hinanden. Jeg er nu så aldeles urokkelig og ivrig i denne Sag, at intet kan formilde mig i så Fald. Jug berler Dem ret venlig at hilse hvem der måske endnu måtte mindes mig i Deres: Omgivelse. Jeg mindes endnu ret godt de allertleste Folk i Vedsted. Ved at lade dem passere Revy forbi mine Tanker, er der kun fa, som jeg ikle kan hitte Rede pấ. Her i Sognet kender jeg meget farre, da jeg næsten aldrig lommer til Nogen uden ved sxrlige Lejligheder. På IIelligaftenerne vil jeg ret karlig mindes Dem, min tro Venincle! og vil De grre Giengæld, sá modes vore Tanker máske under de glodende Julestjerner og svæve hinanden usynlige forbi. Nu Gud evig velsigne Dem og Deres og lader Dem nleve sî mange lykkelige Dage, som det er mit bnske.

Jin kicre Mand sender ved mig de venligste Hikener til Deres kære Mand og Dem, og vi ønsker dem Alle en glæedelig Jul og et velsignet Nytår, ja det give Gud os Alle.

Deres i Liv og Død Dem kærlig hengivne

$$
\text { A. Chr. Ludvigsen. }
$$

Den 13. Februar 1852 skriver hun atter til Veninden i Vedsted: Vi flytter nu snart allerede i April herfra, men ikke langt bort, kun til Norre Vollum i Døstrup Sogn i Ribe Amt. Der har min Mand i forrige Uge købt Berthel Refslunds Gard. Jegr medteler dette sà omstændelig, da Berthel Noller, vor gode Ven, som vi beder meddele dette, vistnok kender det nærmere dertil. Vi må nu snarest muligt sælge, og vi har desårsag skrevet til „Dannevirkes" Redaktşr for deri at få det indrykket, der kan De selv få det at læse. Havde Forpagtningstiden for Moller 
varet urle, kunde det have varet passeligt for ham maske. Dersom De skulde vide en sikker Kober, så beder vi om at tæenke derpå. Vi har kobt vor ny Gird til $50(1) 0 \mathrm{Rd}$. og man paistair, ikke for dyrt. Yi kommer nu aldeles ind under Kongeriget, og vor Sjalesorger Provst Koch i Iostrup' leder mảske om sin Lige bảde som 'Taler og Menneske i clet Hele. Jeg har temmelis travlt med Skriven i denne Tid; men den rette Uro og Travlhed vil forst komme, når vi flytter, dog gar Vanen meget. Det er nu sjette Gang, jeg flytter, og med Guds Hjælp den sidste... Ti havde aldrig forladt vor lille bekvemme, venlige Ejendom, hvor vi meget vel kunde have vort Brod, hvis ikke et Par Omstændigheder, og deriblandt Præsten, havle foranlediget os dertil... Gud voligigne Dem og Deres. De venskabeligste Hilsener osv. A. Chr. Ludvigsen.

P'resten, hun ikke kunde med og som ikke liunde med hende, havde varet Kapellan hos hendes Fader or var siden hans Eftermand. Hans Navn var Nikolaj

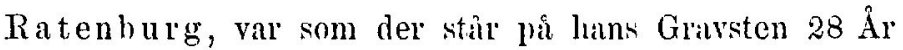
I'rast for Brede Menighed, født på Lindbjergoind i Jylland (red Varde) den 16. Februar 1801, dond i Brede den 29. Marts 1874, og det var hans Svoger og Navnofalle i Bredsted, der var gift med Madame Ludvigsens Slæogtning Auna. Sin ny Sognepræst gar hun et smult Exemplar af sine "Markblomster" $n g$ skrev foran i Bogren:

Hs. Hojærværdighed Hr: Provst Koch, Ridler af $\mathrm{D}$. til Iorstrup med den inderligste Hojagtelse og 'Talknemlighed 
Fuldtro Hyrde! ædie Mand! ved Din Lre, Iit Exempel vises Vej til Livets Land, strømmer Lys fra Herrens Tempel, Kraft og Nåde, Styrke Trøst, 'Tro og Håb i hvert et Bryst.

Tør vi Blomster små og bly - til en Kost nu sammenføjet bede Dig om fredsomt Ly og et venligt Blik fra $\emptyset_{j}$ jet, plantet blandt Din Haves Flor? o hvor blev vor Glæde stor.

Vokset frem i Markens Hegn, fjærni fra Drivehusets Pleje under Solskin, Storm og Regn, er Natur vort hele Eje. Ingen Blomst i Glimmerskær smykker Urtekosten her.

Gerne fryder vi ved Duft, ak, den ânder mat og svælsket, Sommers Tørke, sludfuld Luft, har vor Spires Fremvækst stækket. Ad lle vil Du lytte dug til vort stille Blomstersprog.

Blandt "Markblomsterne" findes i lige Versmål to Digte: „Den faldne Hjærtenskær“ og „Trøst“. Til forstnævnte skrev General Meza Melodi, som han sendte Forfatterinden med folgende I)igt:

\section{Til Digterinden Anna.}

Hvor er det Hjærte i Nord, sum stærkt ej banker ved Mindet om, hvad for Dauskheds Sag troligt Du tifite og led? hror uden Genklang en Sjæl for Din selvopofrenile Troskal, eller en Ånd så sløv, ej at opløftes derved? - 
Herlige Viv, modtag vort Danmarks begejstrede Takord for Dine Tårer i Løn, for Dine dulyte Suk, og for hvert rythmisk Væld, der af Din Kærligheds Fylde vældigt nu sprudler frem, Ynde parret med Kraft. Saga skal nævne Dit Navn, sålænge Dannersprog lyder, Sproget, som Du så rent elskede, skærmede, skrev.

Kjobenhavn, Marts 1852.

Chr. Julius de Meza.

Den 31. Juli 1853 skriver hun til Madame Mortensen: „Hvor det glæclede os at høre, at De havde ræret i Frederits. Hvo der kunde have været så lykkelig! men vi her bo jo sia afsides og sia fjærnt fra enhver l'let, som ved Stordiud blev til helliget Jord, at vi mii slå enhver slig Nydelse af Tankerne og nøjes med den Glade, at det má falde i vore Venners Lod. Jeg kan forestille nig, hvor det mil have skurret i Slesvigholstenernes Øren, og beklager megct den danske Soldat, som på slig en Mindedag, mâtte udholde slige Kammeraters Hản. Ja det vil desvarre vare lienge, for sand Broderkærlighed vil slynge det skønne Fredens Bînd om Dansk og Tysk. I det mindste vil det ikke ske i denne slæxgts 'Tid, som nu lever, og måske ikke i flere derpå forlgende Shwgters Tìd. Forurettelsen fra de Sidstes Side var for stor... Med kærligr Længsel så jeg for fem Uger siden mod Bakkerne ved Vedsted, da min kære Mand og jeg var i Østerlygum at tage Afsked for dette Liv med min nu hedengangne Kusine Kier... Det gleder os, at Kornet i Deres Egn stirr temmelig godt. Her hjælper det sig, undtagen Havren, som er meget mádelig. Af Hø fâr vi nok en 30 Læs mindre end i Fjor. 50 Læs i Steden for 80 . Og her er det endda bedre dermed end i Skærbæk og deromkring, hvor 
der siges, at man nøilsages til at sælge den største Del af Besætningen. Der skal være dem, der på 12 Demat kun fir et Las Hø. Vil den gode Gud blot bevare os for den rælsomme Kolera, som sai frygtelig hærger Hovedstaden, da ma man takke inclerligr og være tilfreds om og med noget mindre end ellers... De må dog hen og se, hvor vi er havnede. Vor Have fik vi ikke anlagt i Foraret, som det var vort Forset, or det var vel en Lykke, da Tørken var så hird. Vil Gud sker det vel til Efteriar, og denne Tid er nok ogsi den rette dertil $-0, \min$ Veninde! hvilken Guds Mand har vi dog her til Sjælesorger! Hvor kan han trøste, opmuntre og glæde Ånden, og oplofte Sindet mod det Evige. Det er en sand Velsignelse for en Meniglied at have slig en Præst. Da jeg var i Storde, kom jeg aldrig i Guds Hus, hvor der intet var at hente uden Argrelse; nu derimod længes jeg hele Ugen efter Søndagen og takker Gud i mit stille Sind for denne Forandringr or Guds Velgerning...

Deres Dem evig tro Veninde

A. Christiane Ludvigsen, f. Lauterup."

Den 23. Januar 1854 skriver hun til sin kæreste Eugrenia jâ Lerskov: „At Nis er kommet til Rødding Højskole synes os megret hensigtsmæssigt. Altsa lille kære Narie gîr til Kontirmation? Ja Du må vel sige, at Tiden gair hurtig, sâ er den unge Skov opvokset og den gamle vil blive omhugget og blive til Aske... Den 12. Januar var det $30 \mathrm{Ar}$ siden min Bedstefader døde orr 20 Âr siden Din kære Fader gik heden. Hvor er dog den Tid bleven af, det er underligt at trenke pia. Nlig synes, det er kun 
kort siden, at jeg red Ranke på Bedstefaders Knæ og lyttede til Fortællinger om Amsterdam og den høje Klippe på St. Thomas, som var slidt ganske glat af Skyerne. Det var den lykkeligste Tid i mit Liv. Hvorledes går det hos Eder med Foder? her er det meget knapt, og kan vi slide os igennem, er det Alt, skøndt vi har færre Kreaturer end ellers, og kun tre Heste. Faders gamle Brune fik en Kugle på Efteråret, og det var den sidste af de levende Skabninger, som han havde ejet. I forrige Uge døde begge mine gamle Hunde, Lion, som jeg alt havde i Vedsted, over $14 \AA ̊$ Ar gl., og den store Fidél, noget yngre. Nu er Alt dødt og borte, hvad jeg havde af Levende, og nu kommer Raden vel først til mig... Hvorledes mon det står til i Vejstrup? Jeg har ikke besvaret Rikkes sidste Brev og kan altså ikke vente Brev der fra. Det er dog meget med Madame Schmidt, hun var tre År ældre end min Fader, lever hun til Maj, går hun i sit 95de $\AA$. . .

Din uforanderlige

A. Christiane Ludvigsen.

Den 9. April skriver hun til Madame Mortensen... En strængere Vinter (Kosakvinteren undtagen) kan jeg ikke huske. Vi har en meget god Kælder; men tilsidst kunde jeg ikke have Mælken der for Frost, og måtte have Alt ind i vor lille Stue. Hvilken rædsom Nyårsdag! Et lignende Uvejr har vi her i mange År iklke hart. Det havde nær sliet vor store Port mod Nord ind, og så Lyn og Torden. Vorherre give, at Året i det hele iklke bliver Begyndelsen lig; Floden stod den 2. Januar lige tæt op til Huset, men forløb snart igen uden at gøre mindste 
Skade. En Del Får druknede i Omegnen... Jeg har hørt af de Lerskover; at Deres Peter og Nis fra Lerskov samtidig har besøgt Højskolen i Rødding. Det er en fortrinlig Indretning, og gi'da Forældre, som kan overkomme det, må følge Deres Exempel! Hrorledes går det Deres agtværdige Degn? Må han endnu døje Ergrelser af Tysksindede? Nu kan de, Gudskelov! ikke drive deres Rænker og Krænkelser så vidt som til en Tid; men det forstår sig, hvo der vil synge, mangler ikke gerne Vise! Det var en rædsom Tid, Oprørstiden! og Ingenting, hverken før eller siden, har gjort et så dybt Indtryk på mig, som den Tids Hændelser. Jeg har fået Hilsen ved Rikke Bonnichsen fra Maren og Christ. Lauritzen, det går dem meget vel. Madame Schmidt går nu næstkommende 18. Maj i sit 96. År og er endnu ret rask. Den tyske Rektor, Christianes Mand, har i Kiiel oprettet en stor Skole og har mange Kostgængere. Det meldte Rikke; ti jeg har ikke noget med Tyskerne at bestille.

Deres indtil Døden tro Veninde

A. Christiane Ludvigsen.

Følgende Digt har hun skrevet til sin Frænde $\mathrm{N}$ is Callesen på Lerskov.

Modtag til venligt Minde, unge Ven, og Gemmested for elskte Venners Navne en liden Bog! - mit Ønske følger den, Gud lad en fuldtro Ven Dig aldrig savne!

Det er en Skat, som gør i Sandhed rig! der fryder Hjærtet, adler Sind og Tanke, gier Mod i Livets Kamp mod Verdens Svig ,og hæver Ånden over Tidens Skranke. 
Er ægte Dannished det skønne Bând, som ædle Ynglingshjærter sammenbinder, da vil den atter vågue, Styrkens Ând til dådfuldt Liv, ornstrålt af Oldtidsminder.

0 , da vil Friheds Sol med himmelsk Glans. bestråle Fæủrevang og Helteyrave, brudsmykket Dana stå med Sejerskrans og Thyra fredet se sin skonne Have.

Ja gid den være nær, den gyldne Tid, da Sydens Rovfuglklo er stakket vorden! der Ende bli'r på Had og blodig Strid, og Fredens Palme skygger over Norden.

Når fjærnt i Fremtid dette Blad Du ser, da minues og Din gamle tro Veuinde, som længrt pá Jordeu da ej fuerdes mer, hvis Stolthed var at kalles Dannekvinde: Norre Tolum, 1*. Oktbr. 1859.

Til venlig Erindring af Anna Christiane Lurvigsen.

Den 1. Marts 1864 skrev hun et Brev til sin Fætter, Maler H. A. Kier, hrori hun klagede over, at Brevhemmeligheden krænkes, hun tyr derfor ikke skrive mere, end hvad enhver i Øjeblikket nå vide, hvilket ikke bliver meget. Der er Hilsen også fra Lorenz, som hun tidligere havde skreret om, at han ikke var af de strerke. Han døde imidlertid kort efter, Påskelørriag den 25. Marts, og nu kom det til at se sort ud for den gamle 70ârige Enke, sá sort som vistnok aldrig nogen Sinde. Ja der kom en Tid, da hun slet ikke var sig selv, ret en „Forargelsens Tid", som hun skrev om Treârskrigens I)age. Paiskedagr, 26. Marts, skrev luun til Sommessmnen af den gamle Farver Jens Johannsen i 'Tinglev: Gátrdejer Jakob Johannsen i Forballum: „Med 
den inderligste Bedrøvelse melder jeg Dem, at min elskede Mage igar Morges Kl. 51/a blev bortkaldt fra denne Verdens Tumleplads til den evige Glæde. I tolv Dage led han af en LungebetændeIse, mod hvilken al Lægehjælp var forgæves. Han forestillede sig Døden fra Begyndelsen af, beholdt Taleevne og Fornuft til sidste Øjeblik. Hans sidste Ord var: „Se! nu er Himlens Porte åbnede for mig!“ I sin Sygdom sagde han flere Gange: Ak, jeg vilde så gerne have ønsket at tale min Ven Jakob Johannsen, og Du må ikke glemme at indbyde ham til mit Æ̇røl! Da jeg ønsker dette lige så meget, så indbyder jeg Dem og Deres til på Fredag, som er den 1. April, at ledsage min dyrebare Lorenz til hans Hvilested, og derefter at tage til Takke med et tarveligt Middagsmailtid her i Huset... Deres oprigtig hengivne

\section{A. C. Ludvigsen."}

Lorenz Ludvigsen var en Husmandssøn fra Brede, hvor han var født 1.816. Som 11-12års Dreng var han kommen til at tjene i Prestegården og kom til at stå højt hos den gamle Præst, der ofte sendte ham med Bud og Pakker over til sin Datter, mens hun var Præstekone i Visby. Da han blev for gammel til at være Dreng kom han over at tjene hos en af Bønderne i Lunde-Randrup. Dog lod Præsten ham kun fare på Vilki̊r, at når hans Avlskarl giftede sig og flyttede, måtte Lorenz komme tilbage og løse ham af. Dette skete, inden Tjenestetiden var omme i Lunde, så Præsten måtte give Løsepenge for at få ham derfra. Som Prestens Avlskarl og Køresvend kom Lorenz til at hente Kristjane og hendes Gods hjem fra Vedsted i Februar 1843. Det mærkedes også snart, at hun havde fattet Godhed for den 28arige Avlskarl. 
Hun havde egentlig onsket at blive Præstekone i Brede ved at gifte sig med Kapellanen N. Ratenborg, der siden: blev hendes Faders Eftermand; men det viste sig, at hun slet ikke kunde sammen med ham, og Forholdet blev da heller ikke videre godt mellem hende og hendes Søskendebarn Enke Bonnichsen, som holdt Hus for Faderen, og hendes Datter, "hendes kære Anna", som blev gift med Nikolaj Ratenborg i Bedsted, hris Søster Louise (1807-87) blev Præstekone i Brede. Men Præsten Ratenborg i Brede måtte i August 1845 på Embedsvegne ægtevie Ungkarl og Gårdejer Lorenz Ludvigsen af Storde til Præsteenken Anna Christiane Jessen, født Lauterup.

Knap 19 År fik de Lov at leve sammen. Folk der på Egnen så op til „Madammen i Vollum“, og „Madammens Mand" var vel lidt af Alle. Hun var den stærke og han den milde. Efter Mandens Død, lod Enken Gården gå til Avktion, boede derefter et Par År i Ribe, men skrev derfra til Jakob Johannsen (29. April 1867): „Højstærede, kære Ven! Jeg må dog melde Dem, at jeg til Efterår (i Oktober) flytter fra Ribe, og har lejet Deres Fætters, Farver Johannsens Aftægtshus i Tinglev, til min fremtidige Bolig. Jeg kan slet ikke vænne mig til det for mig ubehagelige Købstadsliv, men længes efter landlig Frihed og Ugenerthed." Hun flyttede altså til Tinglev, hvor hendes Ungdomsven, Beyer fra Harrislev, var den gamle Præst og hvis Broderdatter, Bothilde Beyer, der blev gift med Præsten Johannsen, var hendes Yndling.

I Digtet: „Mit Livs Kventyr" giver Digterinden i kraftige Billeder en Fremstilling af sit Levnetsløb. I Brevet. til Madame Mortensen i Slukefter (14. Decbr. 1851) bruger hun, som vi har set, tildels de samme Billeder, si Digtet 
er vel fra samme Tid. Efter at have skildret sin Vår og sin Sommer, synger hun:

Den lange Sommer sank i Tidens Skød, fă var de Glædesroser den mig bød, dog lutrede dens Torden Sjæl og Hjærte. Den Blomst, som trives bedst i Storm og Slud, Tálmodighedens Blomst blev klækket ud, hvis Underkraft kan lindre hver en Smerte.

$\mathrm{Nu}$ smiler Livets stille Efterår, end mangen venlig Blomst på Vejen står, hvis Ynde lokker Smilet i mit $\emptyset j \mathrm{je}$. Alt er så roligt nu i dybe Bryst, ej vrede Bølge skummer mer mod Kyst, blidt smiler Fred, og glemt er Kamp og Møje.

Snart kommer Du, o Vinter sølverhvid, den triste Vandrers stille Hviletid og bringer mig den skønne Nyårsmorgen, da Livets Sol forklaret stiger frem, og Ånden vågner hist i Lysets Hjem at prise Gud for Alt, vel mest for Sorgen.

Denne sidste Tanke var hendes kære, stadige Tanke, dog ikke sáledes, at hun derover glemte Livets Opgaver i Øjeblikket. Hun har i Tinglev vundet et smukt Eftermæle. Sit Værelse havde hun prydet med 24 Dannebrogsflag og med danske Billeder af Kong Frederik den Syvende, Skamlingsbanke osv. Hun modtog gerne som Gæster Venner som Jakob Johannsen og Slægtninge fra Østerløgum, ikke at tale om Sognets og Omegnens Folk. Mange er de, der har lyttet til hendes fængslende og oplivende Fortællinger, hvorom også Svend Grundtrigs Samlinger kan bære Vidnesbyrd. Endnu mens hun el Præstekone i Vedsted eller i al Fald kort efter skrev hun

Min Spinderok:

"Det bruser fælt derude, kom Rok, min vante Tidsfordriv!

lad hyle så og tude, her smiler Lyst og Liv. 
Du skræmmer Sorg og Harme, opvarmer venlig Blod og Sind; ti kom i mine Arme, lul mig i Drømme ind.

Mens travle Finger tvinder, og Foden træder som i Dans omsvæve slukte Minder min Sjæl i Trylleglans. Skøndt al Naturen stormer, lig Hjulets Fart er Tankens Gang, som ofte mildt sig former til simpel, kunstløs Sang.

Du var min tro Veninde lig Harpen hist fra Ungdoms Vär; jeg synge vil og spinde, indtil jeg heden går. Ej nogen Fryd jeg savner, o, Eders Selskab er mig nok, og lige varmt jeg favuer min Harpe og min Rok.

Jegr Tråde spandt med Glerle til Livets lyse Brudedragt, til mangt et Dorlningklæde, som længst i Null hlev lagt. Suart spinder jeg det sidste, et Lagen fint or hvidt som Sne, at pryde sorten Kiste, min egen Jordeble.

Fra Rokken Snurren lyder ved Mirhatstid lig Ânderøst, den Dødens Komme tyder, de Godes Hâb og Trøst, da vil jeg Linet sømme alt efter fromme Fæilres Vis og salig vil jeg dromene mig ind i Paradis.

Der fiuder jeg de kære, soln læurst frat Jorden vaudred hjem, forladt vil Harpen vrere, ej mere hentes frem. 
Og støvet, stum og rusten

min Rok vil stå i Ensomhed;

ii Livets Tråd er brusten

og Hånden segnet ned!"

Blandt hendes efterladte Breve tindes flere fra Tinglev til Jakob Johannsen og til Madame Callesen pá Lerskov. Jakob Johannsen takker hun, fordi han har grastet hende, og den 21. Ang. 18\%: skriver hun om sin Lorenz: Ak hvem der kunde forlade Verden med hans sidste Ord: Se nu âbnes Himlens Porte for mig! (xud give mig Nide or Kraft, skint i Svaghed at stræbe derefter, at jeg ved Banens Ende mâtte findes vardiug til at genforenes med ham og med de andre formuangne klskerle! Jeg tæunker tidt pá, hvilken Lylike og Gilade, let vilde have været for mig at have været i l)eres og Families Nærhed; ti hos Dem fincler jex det, som af Alt tiltaler mig mest,

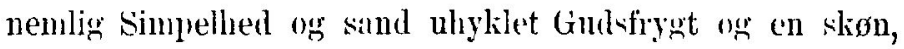
javn Fromhed, uden Bram, men i Oprigtighed or Samblhed. Ak, jeg foler ming ofte si ene og forladt; ti i hror vunlig og forekommende mine Omgivelser er imod niig, sâ savner jew dog at kunne merldele mig om det, som er mig let kareste og mest magtpailiggende, nemlig at tale om hojere Ting. IIvad el hele Verden med sine forfongelige Glader og Lyst, ak kun et Intet, en Sxbeboble, som hrister, et Stigrneskul, som farer hen uden spor!! Men hrad der er af Ginl, er eviert.

Til Marlame ('allesen i Lerskor, lendes kate Eugenia, skriver liun (16. ()lith!: 1873): .Tak for Dit venlige Brer, og fordi Du er tilfied med Garnet. Jens skriver sa hurtigt for at sige I)is, al jor hjærtelig gerne vil spinde til en Fjole for Laler Alle, Hame og I sin somnckone merdiberegnede, og lian tage filt på det, når det passor Eler. At 
spinde Kææmt, er ikke s̊̊ sent, som Du synes at tro, jeg kan temmelig hurtig spinde et Pund. Vil I have det endnu finere, kan I fả det... En sådan Sommer som den, kan jeg ikke huske, man har jo næsten ingen Sommer havt. Jeg vil håbe, at I har fảet Eders Korn bjærget, da Du ikke klager derover. Her har de fleste fáet det." Derefter skriver hun om et overdadjgt Gæsteri hos en Familie, som enten selv er i Visit eller har Huset fuldt af Gæster på længere Tid, og tilføjer: „Jeg takker min Gud og Skaber for min rolige Hytte og holder mig fra det Hele." Det var altså ikke den Slags Selskabelighed, hun yndede. "For vort Udkomme tør hverken I eller jeg, som så Mange desværre skal, sørge.“ Men det var sådanne Småkårsfolk, hun gerne omgikkes med og gerne vilde dele sin Formue med. Det er således sagt, at hun om Lørdagen gjorde stort Indkøb af Kød og om Søndagen lod lave Suppe, sa der var nok til at mætte Mange. „Gud lad Eder Alle nyde Surdhed og Tilfredshed, som er det bedste i denne urolige Verden, og lad os med Fortrøstning håbe på en skønnere Tilværelse, når Timeglasset er udrundet... Jeg har plantet flere Blomster til Dig: En Asclepia, en rød og hvid Fuchsia, en Partania og andre fler, som Du (vil Gud) kan få til Forår. Dem, jeg fik af Dig, har alle blomstret "

Da hun skrev dette, var hun tæt ved de $80 \AA$ r ; men der var endnu mere for hende at udrette i denne Verden. Efter sine Forældre havde hun arvet Trangen, Karligheden! Trang til at hjælpe evnerige unge Mennesker frem mod deres Mål. Hun var som Alle, der på den Vis vil gøre Gavn, ikke altid lige heldig og oplevede vel nok mer end èn bitter Skuffelse ved at tage Lygtemand for 
Stjærne. Imidlertid er det ikke Skuffelserne vi skal dvæle ved. Og her skal vi blot nævne èn af de unge Mænd, hun fik Glæde af: Smedesønnen fra Tinglev Jeremias Christensen. Flere end hun havde lagt Mærke til hans Talent, bl. a. til at skære fint ud i Træ, og da en legemlig Lyde gjorde ham uskikket til Smedehåndværket eller lignende, kunde der ikke være nogen Fristelse til at holde ham tilbage ved dette. Ved Madame Ludvigsens Hjælp gik han til Kunstakademiet i København og blev uddannet som Billedhugger. Ham gjorde hun $i$ sit Testamente til en af sine Arvinger. I Tinglev Kirke indmuret $i$ den nordlige Væg, skrås for Prædikestolen, findes indsat det Billerde (Basrelief), hvorved han vandt det danske Kunstakademis lille Guldmedaille. Dette Billede er en Prædiken til "Trøst i Trængsel" og fremstiller Josef i det ægyptiske Fængsel i Færd med at udtyde Mundskænkens og Bagerens Drømme. Der sad Josef i Fængsel, skyldt for Brøde, han havde været fristet til, efter falsk Vidnesbyrd af uærlige og upålidelige Trælle, som han ikke havde villet hæle med. Men da Nøden var størst, var Hjællyen nærmest fra Gud, "der leder Kongers Hjærter som Vandbække i sin Hånd.“

Da Digterinden kom til Tinglev, var det tyve År siden den brave Farver, hendes Faders Discipel, Peter Johannsen (født 17. Januar 1771, død 4. Februar 1848) var gået til Hvile; men endnu levede hans gode Enke Kjestine Johannsen, født Lorenzen (født i Bajstrup 18. Febr. 1793, død i Tinglev 17. Septbr. 1870), Faster til Karsten Thomsens Svigerfader, den almenagtede Kroejer Johannes Bjørn Lorenzen i Frydendal. "Anna“ levede endnu længe efter den Tid, hun fik først „Hjemlov“ 28. Juni 1884. Hendes Støv gemmes i Farverens Gravsted, 
og ved Siden af gamle Kjestine Johannsens Mindesten stâr hendes med folgrende Indskrift: "Anna Christian e Lud vigsen, født Lautrup, født i Abenrå 14. A pril 1794, død i Tinglev 28. Juni 1884. -- Phil. 1,23. Jeg haver Lyst at vandre herfra." 